Note: This might not be the Publishers version

Click here to order the publishers version via your library

See discussions, stats, and author profiles for this publication at: https://www.researchgate.net/publication/274763908

\title{
Strength of fine-grained soils at the solid-fluid transition
}

Article in Géotechnique · March 2012

Dol: 10.1680/geot.9.P.069

\section{CITATIONS}

40

4 authors:

Mark Randolph

University of Western Australia

342 PUBLICATIONS 8,310 CITATIONS

SEE PROFILE

9. Nathalie Boukpeti

University of Western Australia

22 PUBLICATIONS 158 CITATIONS

SEE PROFILE
347

David J White

University of Western Australia

248 PUBLICATIONS 4,012 CITATIONS

SEE PROFILE

Han Eng Low

Fugro World Wide

23 PUBLICATIONS 382 CITATIONS

SEE PROFILE

Some of the authors of this publication are also working on these related projects:

Instrumented Free Fall Sphere View project

My PhD View project 


\title{
Strength of fine-grained soils at the solid-fluid transition
}

\author{
N. BOUKPETI*, D. J. WHITE*, M. F. RANDOLPH* and H. E. LOW
}

\begin{abstract}
Deepwater offshore oil and gas developments require an assessment to be made of the risk of infrastructure damage from submarine slides. The likelihood and magnitude of submarine slides, and the consequent impact loading on seabed infrastructure in the path of the debris from the slide, must be estimated. Export pipelines are especially vulnerable to impact from submarine slides, because of their length and the need to cross canyons and other seabed features that are potential paths for the flowing debris. Characterising the debris material represents a particular challenge, as the original soil, which is typically characterised using conventional geotechnical methods, evolves through remoulding and water entrainment into a viscous fluid. Because of this transition from soil to fluid, characterisation of the strength of flowing fine-grained sediment has been addressed separately within a soil mechanics framework and a fluid mechanics framework, resulting in two different approaches for expressing the strain-rate-dependent strength of debris flows, and the consequential impact loads on pipelines. In this paper we compare the two approaches, and show that the geotechnical characterisation of fine-grained sediments can be extended into the liquid range in a continuous fashion. This is supported by a series of undrained shear strength measurements on two different remoulded soils, from fall cone tests, vane shear (including viscometer) tests, T-bar and ball penetrometer tests. Analysis of the results shows that the variation in shear strength over the solid and liquid ranges can be described by a unique function of water content, for a given soil. Furthermore, the effects of rate of shearing are well captured by a dimensionless function of the normalised strain rate. The geotechnical approach also accounts for the observed strength reduction due to intense shearing.
\end{abstract}

KEYWORDS: clays; constitutive relations; landslides; in situ testing; shear strength
Les développements dans le secteur du pétrole et du gaz offshore en haute mer nécessitent une évaluation des risques d'endommagement de l'infrastructure sous l'effet de glissements de terrain sous-marins. Il est nécessaire d'estimer la probabilité et l'envergure de glissements de terrain sous-marins, ainsi que les charges dynamiques sur l'infrastructure du fond marin sur le chemin des débris découlant du glissement de terrain. Les pipeline d'exportation sont particulièrement vulnérables à l'impact des glissements de terrain sous-marins, en raison de leur longueur, et de la nécessité de traverser des canyons et autres accidents du terrain sur le fond marin, qui deviennent des chemins potentiels pour l'écoulement de débris. Caractériser les matériaux des débris devient un problème de taille, du fait que le sol original, caractérisé à l'aide de méthodes géotechniques traditionnelles, évolue sous l'effet du remoulage et de l'entraînement d'eau qui en font un fluide visqueux. En raison de cette transition de sol à fluide, la caractérisation de la résistance de sédiments à grain fin qui s'écoulent a fait l'objet d'un examen distinct dans le cadre de la mécanique des sols et de la mécanique des fluides, en donnant lieu ainsi à deux principes différents pour exprimer la résistance des coulées de boue en fonction de la vitesse de déformation, et les charges dynamiques conséquentes sur les pipelines. La présente communication compare ces deux principes, et démontre qu'il est possible de poursuivre, de façon continue, la caractérisation géotechnique de sédiments à grains fins dans la plage liquide. Ce principe est supporté par une série de mesures de la résistance au cisaillement non drainée effectuées au pénétromètre cône, au scissomètre (y compris au viscosimètre), au pénétromètre à barre en $T$ et boule, sur deux sols remoulés. L'analyse des résultats montre qu'il est possible de décrire les variations de résistance au cisaillement dans les phases solide et liquide par une fonction unique de teneur en eau pour un sol donné. En outre, les effets du taux de cisaillement sont exprimés parfaitement par une fonction sans dimension de la vitesse de déformation normalisée. La méthode géotechnique se penche également sur la réduction de la résistance observée, attribuable au cisaillement intense.

\section{INTRODUCTION}

This paper is concerned with the strength of fine-grained soils when remoulded and subjected to changes in moisture content that span the solid-fluid boundary. The behaviour of soil in these conditions governs the run-out of submarine slides, and the impact loading exerted by slides on obstacles such as pipelines. In general, as a submarine slide runs out, the flowing material changes gradually from the original

Manuscript received 22 May 2009; revised manuscript accepted 12 April 2011.

Discussion on this paper is welcomed by the editor.

* Centre for Offshore Foundation Systems, The University of Western

Australia, Perth, Australia.

$\dagger$ Advanced Geomechanics, Perth, Australia. intact conditions into a weak debris and ultimately to a fluidised turbidity current.

Deepwater offshore oil and gas developments require an assessment to be made of the risk of infrastructure damage from submarine slides (Jeanjean et al., 2005). Slide hazards range from giant historic slides that may be reactivated, such as the Storegga slide off the coast of Norway (Bugge et al., 1998), to regions where mudslides are activated on a more regular basis, such as the margins of the Mississippi delta, where mudslides are triggered by major hurricanes (Gilbert et al., 2007). Designers must estimate the likelihood and severity of future slides, and the consequent impact loading on seabed infrastructure caused by the slide material. The broader topic of submarine mass movements also governs the evolution of coastal seabed topography, and recent research has studied the possibility of submarine slides trigger- 
ing tsunamis (Ward, 2001; McAdoo \& Watts, 2004). Recent review articles related to submarine slide behaviour are presented by Locat \& Lee (2002) and Masson et al. (2006). Zakeri (2009) and Parker et al. (2009) review the limitations of current engineering practice related to slide-infrastructure impact behaviour, and highlight the difficulties associated with the quantification of slide strength and the resulting impact forces.

The process of slide failure, run-out and fluidisation is accompanied by a change in strength (or mobilised shear stress) of more than three orders of magnitude. Also, the strain rate within the deforming soil is typically far higher than the strain rates considered in usual geotechnical problems. To illustrate the range of behaviour under consideration, Fig. 1 shows an idealised cross-section through a seabed slope. A submarine slide is shown with indicative values of the mobilised shear strength, velocity and density, based broadly on reported values and typical conditions for fine-grained seabed sediments (Schwab et al., 1996; Locat \& Lee, 2002; Marr et al., 2002; Masson et al., 2006). An additional variable relevant to this study is the strain rate within the deforming material. Based on a slide thickness of $1-10 \mathrm{~m}$ and a velocity at the slide crest in the range 1$50 \mathrm{~m} / \mathrm{s}$, a strain rate range of $0 \cdot 1-50 \mathrm{~s}^{-1}$ can be estimated, based on the idealisation of uniform strain throughout the depth of the slide. If the flow comprises a plug of material over a thin shearing zone, then the strain rate within the shearing zone would be higher.

Two key challenges in the analysis of submarine slides, and their interaction with infrastructure, are: (a) the development of suitable models to capture the strength behaviour of seabed sediments across the solid-fluid boundary (spanning typically three orders of magnitude in strength, or mobilised shear stress); and (b) the assessment of parameters for these models for a particular soil type (Locat \& Lee, 2002; Marr et al., 2002).

This paper describes a study of the rheology of two different soils across a range of water content that spans between the conditions relevant to intact soil and to a weak fluidised submarine slide. A key aim of this study is to devise a basis for characterising the strength behaviour of both a fluid-like material (relevant to the final run-out stages of a slide) and a solid material (representative of the intact material), using the same type of material model. The benefit of a unified framework is that it provides the potential for the full process of slide triggering, run-out and resedimentation to be simulated without the need to distinguish between different material phases, nor to discard the geotechnical framework that underpins conventional engineering techniques for site characterisation and the design of seabed infrastructure. This paper explores the applicability of potential models for the slide material behaviour, considering approaches that originate from the fluid dynamics and solid mechanics disciplines.

In the following section, the strength models and strength measurement methods that form the background of the experimental study are presented. The testing programme includes fall cone tests, vane shear and viscometer tests, and miniature T-bar and ball penetrometer tests, conducted in remoulded soils with strengths varying across three orders of magnitude, corresponding broadly to the conditions illustrated in Fig. 1. Analysis of the results focuses on three influences on undrained shear strength (or mobilised shear stress): water content, strain rate and remoulding.

\section{BACKGROUND THEORY \\ Strength models}

In this section, the basic frameworks for soil mechanics models and for fluid mechanics models are reviewed, pointing out similarities and differences.

Soil mechanics framework. Most modern constitutive models for clays are based on the critical state framework, which postulates a unique relationship between the mean effective stress, shear strength and water content (or void ratio) at failure (Roscoe et al., 1958; Schofield \& Wroth, 1968; Muir Wood, 1990). This framework is based on observations from laboratory experiments on clays, indicating that all loading paths during drained or undrained shearing terminate on the critical state line (CSL). This line can be represented by the relation

$$
s_{\mathrm{u}}=\frac{M}{2} p^{\prime}
$$

with

$$
p^{\prime}=\exp \left(\frac{N-v}{\lambda}\right)
$$

where $s_{\mathrm{u}}$ is the undrained shear strength of the clay (defined as the radius of the largest Mohr circle at failure); $p^{\prime}$ is the mean effective stress; $v$ is the specific volume (i.e. $v=1+e$, where $e$ is the void ratio); and $M, N$ and $\lambda$ are soil constants. The constant $M$ reflects the frictional proper-

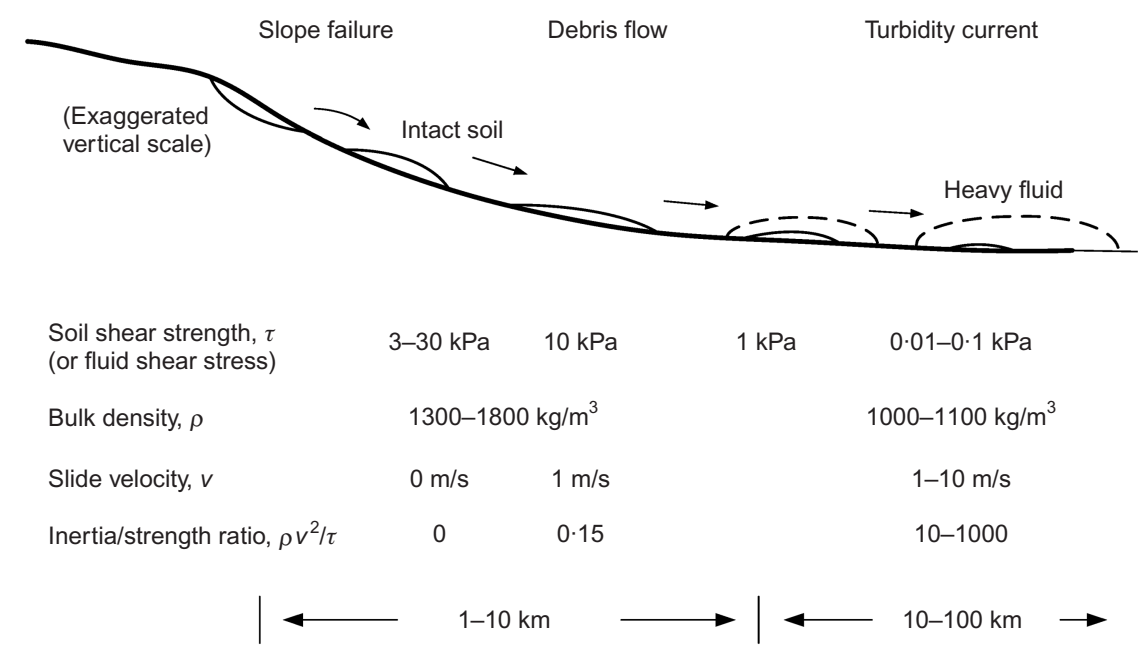

Fig. 1. Schematic diagram of key submarine slide characteristics 
ties of the soil, and may be expressed in terms of the friction angle, $\phi^{\prime}$, measured in triaxial compression as $M=6 \sin \phi^{\prime} /\left(3-\sin \phi^{\prime}\right) ; N$ is the specific volume at unit mean effective stress; and $\lambda$ is the one-dimensional compressibility (proportionality coefficient between $v$ and $\ln \left(p^{\prime}\right)$ ).

The critical state concept can be combined with correlations between soil index properties and shear strength. Based on reported laboratory data, Wroth \& Wood (1978) proposed adoption of the following assumptions: (a) the shear strength of soil at the liquid limit is about $1.7 \mathrm{kPa}$; (b) the shear strength at the plastic limit is 100 times larger, i.e. $170 \mathrm{kPa}$. These assumptions, combined with the critical state relations, yield the idealised relationship (Fig. 2)

$$
s_{\mathrm{u}}=170 \exp (-4 \cdot 6 \mathrm{LI})(\mathrm{kPa})
$$

where $\mathrm{LI}=\left(w-w_{\mathrm{PL}}\right) /\left(w_{\mathrm{LL}}-w_{\mathrm{PL}}\right), w$ is the water content, and $w_{\mathrm{PL}}$ and $w_{\mathrm{LL}}$ are the water contents at the plastic limit and liquid limit respectively. Equation (2) provides a simple tool for estimating the undrained shear strength of remoulded clays from index tests.

It is widely recognised that soils sheared at different strain rates show different shear strengths, and this has customarily been expressed through a parameter $\mu$, giving the proportional change in shear strength for each order of magnitude change in strain rate (Dayal \& Allen, 1975; Biscontin \& Pestana, 2001; Einav \& Randolph, 2005). Thus the shear strength at a strain rate of $\dot{\gamma}$ is expressed as

$$
s_{\mathrm{u}}=s_{\mathrm{u}, \mathrm{ref}}\left(1+\mu \log \frac{\dot{\gamma}}{\dot{\gamma}_{\text {ref }}}\right)
$$

where $s_{\mathrm{u}, \mathrm{ref}}$ is the shear strength at the reference shear strain rate of $\dot{\gamma}_{\text {ref }}$. For application in analysis, a minimum shear strength must be specified at low rates of shear strain. Typical values of the coefficient $\mu$ lie in the range $0 \cdot 1-0 \cdot 2$ (or $10-20 \%$ change in shear strength per log cycle) (Graham et al., 1983; Lunne \& Andersen, 2007). An alternative expression of the effect of shear strain rate is a power law, expressed as (Biscontin \& Pestana, 2001)

$$
s_{\mathrm{u}}=s_{\mathrm{u}, \mathrm{ref}}\left(\frac{\dot{\gamma}}{\dot{\gamma}_{\text {ref }}}\right)^{\beta}
$$

with the values of the parameter $\beta$ generally in the range $0 \cdot 05-0 \cdot 17$ (Jeong et al., 2009).

The strength of a soil is also affected by the cumulative amount of applied strain. Generally, an intact soil exhibits a peak in mobilised stress during initial shearing, followed by a gradual decrease, owing to the destructuration of soil microstructure (such as chemical bonding), reorientation of

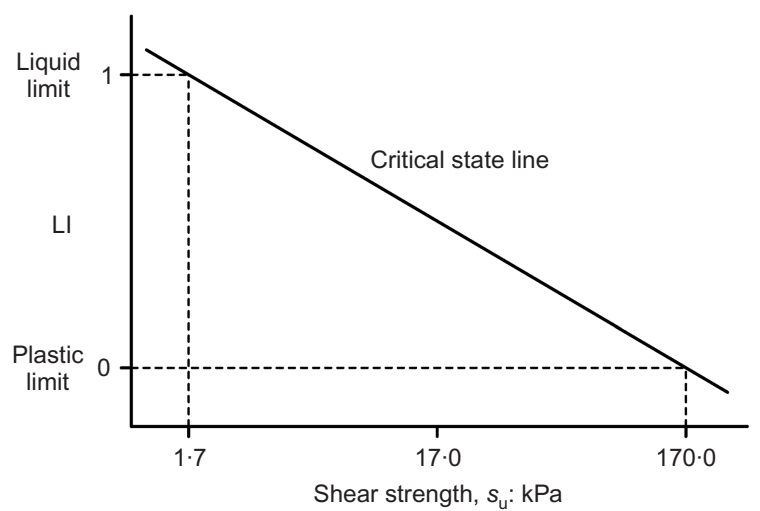

Fig. 2. Idealised relationship between liquidity index and shear strength (after Wroth \& Wood, 1978) clay particles, or the generation of excess pore pressure. This strength reduction can be modelled through a simple exponential decay function (Einav \& Randolph, 2005) as

$$
s_{\mathrm{u}}=\left[\delta_{\mathrm{rem}}+\left(1-\delta_{\mathrm{rem}}\right) \mathrm{e}^{-3 \xi / \xi_{95}}\right] s_{\mathrm{u}, \mathrm{p}}
$$

where $\delta_{\text {rem }}$ is the inverse of the sensitivity, and $\xi$ is the cumulative plastic shear strain, with $\xi_{95}$ being the plastic shear strain required to achieve $95 \%$ remoulding.

Fluid mechanics framework. The constitutive behaviour of a fluid in motion is generally described by a relation between the shear stress in the fluid and the rate of shear strain. Examples of this type of relation are shown in Fig. 3. The most common fluid flow model is Newton's law of viscosity, which relates the shear stress in the fluid to the shear strain rate by means of a proportionality constant called the dynamic viscosity. By extension, the term 'viscosity' is generally used to refer to the slope of the shear stress-strain rate curve. Fluids that do not obey Newton's law of viscosity are known as non-Newtonian. For example, in fluids containing a certain proportion of solid particles in suspension, the shear stress, $\tau$, must reach a minimum value, $\tau_{\mathrm{y}}$, before flow commences. This type of behaviour is called plastic, and can be described by the general relation

$$
|\tau|=\tau_{\mathrm{y}}+\eta|\dot{\gamma}|^{n}
$$

where $\eta$ represents the viscous property of the fluid. With $n$ equal to 1, equation (6) represents the two-parameter Bingham model, which assumes a linear variation of the shear stress with shear strain rate, once the yield stress is exceeded. In its general three-parameter form, equation (6) is referred to as the Herschel-Bulkley model, which assumes a non-linear response, with either an increase in viscosity (shear thickening with $n>1$ ), or a decrease in viscosity (shear thinning with $n<1$ ) with increase in strain rate. The Herschel-Bulkley model is found to represent adequately the behaviour of kaolinite suspensions (Wan, 1982), or actual debris flow material (Coussot et al., 1998). The model has been implemented in the numerical code BING, developed to model submarine landslides, following a fluid mechanics approach (Imran et al., 2001; De Blasio et al., 2004). The Herschel-Bulkley model, with $\tau_{\mathrm{y}}=0$, is exactly equivalent to the soil mechanics power law model (equation (4)) where $\eta=s_{\mathrm{u}, \mathrm{ref}} / \dot{\gamma}^{\beta}$ ref and $n=\beta$.

Empirical relationships are generally used to relate the change in yield stress and viscosity to the change in volumetric concentration of solids, $C_{\mathrm{sv}}$ (O'Brien \& Julien, 1988; Major \& Pierson, 1992), which is the quantity com-

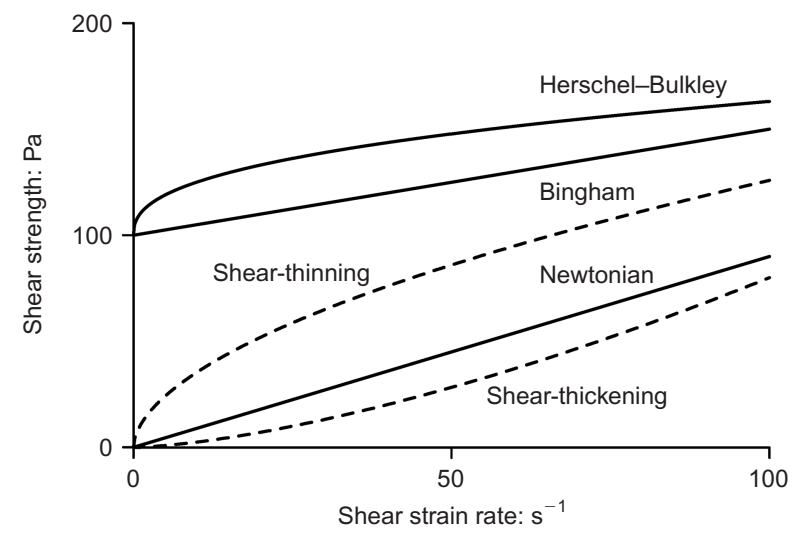

Fig. 3. Fluid models for viscous strength 
monly used within the fluid dynamics literature instead of moisture content. These are in the form of exponential functions

$$
\begin{gathered}
\tau_{\mathrm{y}}=\alpha_{2} \mathrm{e}^{\beta_{2} C_{\mathrm{sv}}} \\
\eta=\alpha_{1} \mathrm{e}^{\beta_{1} C_{\mathrm{sv}}}
\end{gathered}
$$

with the parameters $\alpha_{1}, \alpha_{2}, \beta_{1}, \beta_{2}$ being in the ranges 1 to $10^{-4} \mathrm{kPas}$ (for $n=1$ ), $10^{-1}$ to $10^{-5} \mathrm{kPa}, 7$ to 50 and 7 to 100 respectively.

Comparison of the two frameworks. The Herschel-Bulkley model proposed within the fluid mechanics framework, and the logarithmic and power law soil models for rate-dependent shear strength are all able to represent the non-linear variation of shear stress with shear strain rate observed experimentally. However, the two types of formulation differ by the fact that the effect of strain rate on the shear strength is accounted for by an additive term in the case of the fluid approach, and a multiplicative term in the case of the soil mechanics approach. An advantage of the multiplicative formulation is that the rate dependence is expressed in terms of dimensionless quantities. This allows the effect of strain rate to be described by a single parameter that is independent of both the shear strength and shear strain rate levels. Furthermore, defining a reference shear strength at a reference strain rate in the soil mechanics approach reduces the inaccuracy due to the difficulty of interpolating the shear stress at zero strain rate to determine the yield stress.

\section{Strength measurements}

This section reviews briefly the various strength measurement methods used to characterise soft seabed soils, giving some indications where possible of the rate of strain involved.

Methods to measure shear strength may be divided broadly into two categories: element tests (such as a triaxial test); and 'intrusive' tests (such as vane shear and penetrometer tests). By their nature, element tests will always be carried out in a laboratory environment (even if the laboratory is offshore), whereas intrusive tests may be carried out in the field (in situ), or in the laboratory, on either intact or remoulded material.

Element tests include triaxial compression and extension tests and simple shear tests, generally with the sample enclosed in a membrane and consolidated under defined effective stresses. Applied strain rates are typically in the range $1-5 \% / \mathrm{h}\left(\sim 3\right.$ to $14 \times 10^{-6} \mathrm{~s}^{-1)}$. However, the range of shear strengths considered in this paper is too low to allow accurate conventional element tests of this nature.

The intrusive tests included in this study include fall cone, T-bar and ball penetrometers, and vane shear (including viscometer). These are considered further below.

Fall cone. The fall cone is essentially a strength test, even though it is most often used to determine the liquid limit. The formulation for interpreting the shear strength, as proposed by Hansbo (1957), depends crucially on the correlation parameter $K$

$$
s_{\mathrm{u}}=\frac{K Q}{h^{2}}
$$

where $Q$ is the cone weight and $h$ is the penetrated depth. Although the test involves the highest strain rates of any of the tests (estimated as $1-10 \mathrm{~s}^{-1}$ by Koumoto \& Houlsby, 2001), historically the value of $K$ has been determined by correlation with slower tests, such as triaxial tests, where the strain rate is more typically less than $25 \% / \mathrm{h}\left(70 \times 10^{-6} \mathrm{~s}^{-1}\right)$ or vane shear tests, where the strain rate is $\sim 0 \cdot 1 \mathrm{~s}^{-1}$ (Einav \& Randolph, 2006). Therefore its classification will depend on how the test is interpreted. In this paper, theoretical values of $K$ have been taken from Koumoto \& Houlsby (2001), and therefore it should be viewed as an extremely high strain rate test (Fig. 4). Assuming a semi-rough cone surface, $K=1.33$ for a $30^{\circ}$ cone, and 0.305 for a $60^{\circ}$ cone.

Vane shear and viscometers. In this study, the term 'viscometer' is used to distinguish the vane shear used to test soils from the low-aspect-ratio, six-bladed vane used in low-strength materials such as slurries. Although not used in this study, concentric cylinder shear devices (often called 'rotational viscometers') are mentioned here briefly, as they are commonly used to test slurries (O'Brien \& Julien, 1988; Major \& Pierson, 1992). In a vane or viscometer test the device is first pushed into the soil, leading to local remoulding and changes in stresses, after which a waiting period is allowed before the vane is rotated at a given rate. The strength deduced from the measured torque is affected by the details of the test, including the waiting time and rotation rate (Chandler, 1988). The formulation relating the operative undrained shear strength to the measured resisting torque is given by

$$
s_{\mathrm{u}}=\frac{T}{\frac{\pi D^{2}}{2}\left(H+\frac{D}{3}\right)}
$$

where $D$ and $H$ are the diameter and height of the vane. This relationship is based on the assumption of a uniform stress distribution on the top and bottom ends of the soil cylinder mobilised by the vane. Nguyen \& Boger (1985) demonstrated that the constant stress assumption is a reasonable one, especially for vanes with height-to-diameter ratios greater than or equal to 2 . In the present study the vane has a ratio $H / D=2$. However, the viscometer has a much smaller ratio of $H / D=0 \cdot 72$.

The strain rate imposed on the soil by the vane is not well defined, since the analysis assumes a velocity discontinuity at the cylindrical and horizontal surfaces confining the vane. For a rate-dependent material the velocity discontinuity will be smeared, resulting in a finite shear strain rate. For vane tests conducted at the standard field rate of $0.1 \%$, in material with a strain-rate dependence of $10 \%$ per log cycle, the maximum shear strain rate may be calculated as $0.05 \mathrm{~s}^{-1}$ (Einav \& Randolph, 2006). Similarly, for a rotation rate of

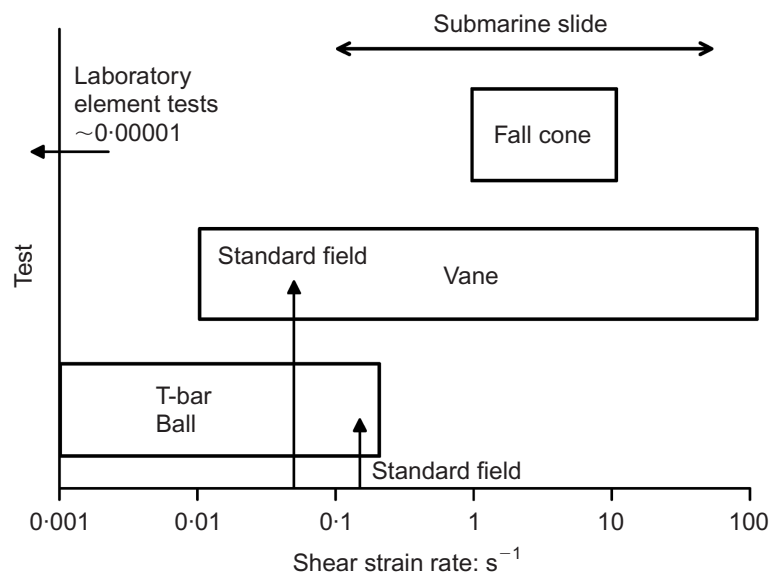

Fig. 4. Typical strain rates for strength measurements 
$1 \%$ (which was used in this study), the maximum shear strain rate is about $0.5 \mathrm{~s}^{-1}$. (Note that the relationship is not exactly proportional, and also depends slightly on the rate dependence and the choice of reference shear strain rate, but these are second-order effects.)

For a viscometer where the soil is sheared between two concentric cylinders, the shear strain rate may be calculated directly as the differential velocity divided by the gap between the cylinders. Usually one of the cylinders will be stationary, so that if the average radius to the centre of the two cylinders is $R$, and the gap is $t$, then the shear strain rate will be $\omega R / t$, where $\omega$ is the angular velocity of the moving cylinder.

Penetrometers. The penetrometers used in the present work are cylindrical (T-bar) and spherical (ball) full-flow penetrometers (Randolph, 2004). Compared with the more conventional cone penetrometer, the simple geometry of these full-flow penetrometers allows improved theoretical analysis in order to evaluate the shear strength from the penetration resistance, and also allows an average 'operative' shear strain rate to be associated with the tests, proportional to the normalised penetration rate, $v / D$, where $D$ is the diameter of the cylinder or ball. The theoretical plasticity solutions of Randolph \& Houlsby (1984) and the experimental data of Stewart \& Randolph (1994) led to the recommendation of a resistance factor $N_{\mathrm{p}}=10 \cdot 5$, to determine the undrained shear strength from the measured penetration resistance of the T-bar or ball $\left(s_{\mathrm{u}}=q / N_{\mathrm{p}}\right)$.

In the field, penetration rates are typically $0 \cdot 5$ diameters per second for the T-bar (a $40 \mathrm{~mm}$ diameter bar, $250 \mathrm{~mm}$ long, penetrated at $20 \mathrm{~mm} / \mathrm{s}$ ), and 0.2 to 0.25 diameters per second for the ball (a ball of 80 or $113 \mathrm{~mm}$ diameter penetrated at $20 \mathrm{~mm} / \mathrm{s}$ ). Numerical analysis has shown that the above penetration rates give rise to operative shear strain rates given approximately by (Zhou \& Randolph, 2009)

$$
\dot{\gamma} \approx 0 \cdot 3 \frac{v}{D}
$$

for the T-bar, and

$$
\dot{\gamma} \approx 0 \cdot 6 \frac{v}{D}
$$

for the ball. These lead to an operative shear strain rate of $\sim 0 \cdot 15 \mathrm{~s}^{-1}$ for both instruments (Fig. 4).

In laboratory testing, penetrometer dimensions are more typically $5 \mathrm{~mm}$ diameter by $20 \mathrm{~mm}$ long for the T-bar, and $12 \mathrm{~mm}$ diameter for the ball, with typical penetration rates for undrained response of $1-3 \mathrm{~mm} / \mathrm{s}$. The maximum shear strain rates are therefore similar to those in the field.

Interestingly, the inferred strain rates in a submarine slide are closer to the operative strain rates during conventional geotechnical in situ tests, such as penetrometer tests, than to the rate in a conventional geotechnical element test.

\section{SOILS TESTED AND SAMPLE PREPARATION \\ Soil types}

Shear strength measurements were conducted on two different types of clay, prepared at different moisture contents into cylindrical samples. One of these was commercially supplied kaolin, and the other was a natural soft clay collected from the Burswood site (denoted as Burswood clay from here on), near the Swan River, a few kilometres upstream of the centre of Perth, Western Australia. Index properties of the two soil types were determined using the Australian Standard (Standards Australia, 1991, 1995), and are reported in Table 1 .
Table 1. Soil index properties

\begin{tabular}{l|c|c}
\hline Property & Kaolin & Burswood clay \\
\hline Liquid limit: \% & $58 \cdot 4$ & $86 \cdot 5$ \\
Plastic limit: \% & 28 & 30 \\
Plastic index: \% & $30 \cdot 4$ & $56 \cdot 5$ \\
Specific gravity & $2 \cdot 6$ & $2 \cdot 6$ \\
\hline
\end{tabular}

\section{Sample preparation method}

Kaolin samples at water content $69 \%$ and above. An initial quantity of the soil was prepared by mixing kaolin powder with distilled water to achieve a slurry with water content of $67 \%$. A Hobart mixer was used to mix the soil until it became homogeneous, after which it was kept for $24 \mathrm{~h}$ in a closed plastic bag prior to testing. Subsequent samples at higher water contents were obtained by adding distilled water successively to the base sample. The same mixing and $24 \mathrm{~h}$ rest procedure was applied for each sample.

Kaolin samples at water content 51-60\%. The kaolin sample at the lowest water content $(51 \%)$ was prepared through consolidation of a slurry under a vertical effective stress of $70 \mathrm{kPa}$ within a consolidation chamber. The slurry was prepared by mixing kaolin powder with water, at a water content of $\sim 120 \%$, in a mixer. The slurry was carefully scooped and placed into the chamber, prepared with a layer of coarse sand to provide a drain at the base. The slurry was placed in layers under water to minimise air entrainment. The chamber was placed under a static press, and the sample was allowed to consolidate for a period of 5 days. At the end of consolidation the soil was scooped out of the chamber, and placed in a plastic bag, ready to be remoulded prior to specimen cylinder preparation. Subsequent samples at higher water content were obtained by adding distilled water to the consolidated sample to achieve the required water contents of $55 \%$ and $60 \%$.

Burswood clay samples. The bulk soil sample from Burswood was wet-sieved using distilled water through a sieve with openings $2 \mathrm{~mm}$ in diameter, in order to remove large shell fragments from the material. The sieved material was mixed with distilled water into a slurry with water content of $\sim 135 \%$ in a mixer. Following the same procedure as for the preparation of kaolin samples, the slurry was placed in a chamber and consolidated to a vertical effective stress of $80 \mathrm{kPa}$. After consolidation, the soil was placed in a plastic bag and remoulded. The water content of the consolidated sample was $66 \%$. Samples at higher water content were prepared by successively adding distilled water to the current sample.

Preparation of specimen cylinder. The cylindrical soil specimen used for vane shear and penetrometer tests was prepared in a plastic container $156 \mathrm{~mm}$ high and $150 \mathrm{~mm}$ in diameter, which comprised six rings, each with a height of $26 \mathrm{~mm}$. Prior to placing the remoulded soil into the cylindrical mould, the sample was hand-remoulded by kneading the soil inside a plastic bag for a period of approximately $15 \mathrm{~min}$. To minimise air entrapment, the cylindrical specimen was prepared in six lifts. Each lift consisted of placing one of the rings that made up the containing cylinder, followed by transferring and kneading of the soil layer using spatulas. At the end of the last lift the top surface of the specimen was 
smoothed flat with a large spatula, and plastic wrap was placed over the surface to prevent drying.

The viscometer tests were conducted on soil samples placed in a small plastic container of $\sim 100 \mathrm{~mm}$ diameter, with a sample height of $\sim 100 \mathrm{~mm}$. For these samples at relatively high water content, remoulding consisted of stirring the soil until the mixture appeared homogeneous.

\section{TESTING EQUIPMENT AND PROCEDURES} Fall cone tests

Fall cone tests were carried out before and after preparation of the specimen cylinder for the vane shear, T-bar or ball penetrometer test, as well as after the actual test had been completed. Each fall cone test was accompanied by water content measurements. This procedure was adopted to detect possible variations in water content and shear strength during specimen preparation and testing. The measured relative variations in water content were within $1 \%$, which is of the order of the error associated with this type of test.

Prior to conducting the fall cone test, the soil was remoulded thoroughly until the soil mixture became homogeneous. The soil was then filled into a cup $56 \mathrm{~mm}$ in diameter and $42 \mathrm{~mm}$ high, with special care taken to avoid air entrapment. The test was carried out by letting the cone fall freely and penetrate under its own weight for $5 \mathrm{~s}$. Three different cones were used, depending on the range of undrained shear strength: a $30^{\circ}$ (apex angle) cone of $80 \mathrm{~g}$, a $60^{\circ}$ cone of $60 \mathrm{~g}$, and a $60^{\circ}$ cone of $20 \mathrm{~g}$.

\section{Vane shear test}

Motorised vane shear tests were carried out to measure the remoulded undrained shear strength of the soil samples at various rotation rates. A four-bladed vane with a diameter of $20 \mathrm{~mm}$ and a height of $40 \mathrm{~mm}$ was used. Measurements of axial and torsional load were obtained by means of a load cell located $50 \mathrm{~mm}$ above the blades. A $3 \mathrm{~mm}$ diameter shaft was used to connect the load cell and vane blade. The tests were performed using a rotary actuator mounted on the actuator used to penetrate the vane blades to the required testing depth at a penetration rate of $1 \mathrm{~mm} / \mathrm{s}$.

After the vane had reached the testing depth of $90 \mathrm{~mm}$ (referred to the tip of the vane), $10 \mathrm{~s}$ waiting time was imposed, followed by the testing sequence at various rotation rates, as depicted in Fig. 5. An initial rotation of $150^{\circ}$ at $1 \%$ allowed measurement of a peak resistance. This was followed by remoulding for ten rotations at $10 \%$ s. Testing at various decreasing rates was then carried out, starting from a rotation rate of $200 \%$, down to $1 \%$ s. The plan was to

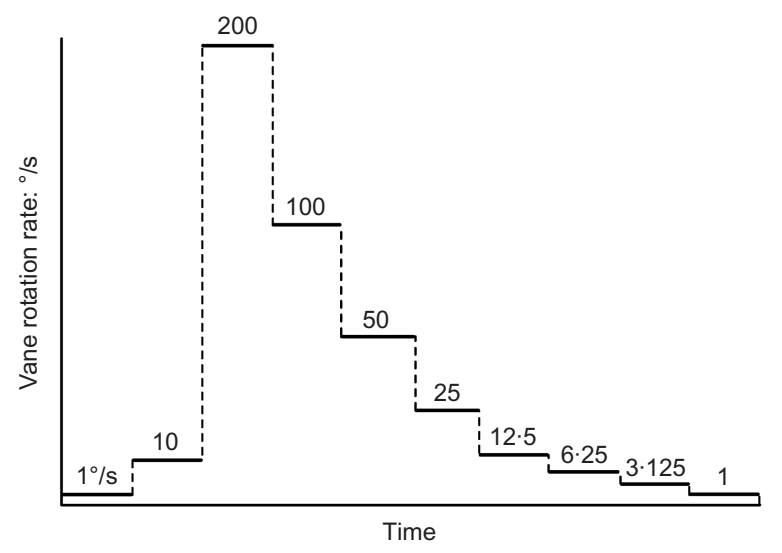

Fig. 5. Sequence of rotation rates applied with the vane and viscometer maintain each rate until stabilisation of the measured resistance, but in practice stabilisation was not always observed.

The test was repeated without the blades, to determine the contribution of the shaft frictional resistance to the measured resistance. The measured shaft frictional resistances were on average only $4 \%$ of the minimum measured shear stress (with a maximum of $11 \%$ ).

\section{Viscometer test}

The viscometer was used to determine the undrained shear strength of the soil samples in the range below $1 \mathrm{kPa}$. The viscometer used is the ViscoTester T550 by Thermo Haake. This viscometer allows measurement of the shear strength at a controlled rotation rate, and consists of a variable-speed motor connected to a torsion head, to which the vane is attached. A six-bladed vane $22 \mathrm{~mm}$ in diameter and $16 \mathrm{~mm}$ high was used.

The test was performed by slowly jacking up the soil sample beneath the vane, until the vane was immersed into the soil with a minimum of one vane diameter of soil above and below the vane. A $10 \mathrm{~s}$ waiting period was then allowed, before a testing sequence similar to the one used for the vane was applied (see Fig. 5). No correction for shaft friction was considered.

\section{T-bar and ball penetrometer tests}

Miniature T-bar and ball penetrometer tests were carried out on the remoulded soil samples at various penetration rates. Two sizes of T-bar were used, namely $40 \mathrm{~mm} \times 10 \mathrm{~mm}$ and $20 \mathrm{~mm} \times 5 \mathrm{~mm}$, and two ball diameters, $24 \mathrm{~mm}$ and $11.9 \mathrm{~mm}$. The larger penetrometers were used in the lower shear strength range to increase the measured load, and thus decrease the relative error due to small fluctuations in the load cell reading due to temperature effects. In addition, the use of larger penetrometers results in longer drainage paths around the T-bar or ball, favouring undrained conditions even for the slow penetration rates.

The tests were performed using an actuator to penetrate the T-bar or ball to a depth of $150 \mathrm{~mm}$ and then apply cycles of penetration and extraction between depths of 70 and $150 \mathrm{~mm}$. The testing sequence at various penetration rates is depicted in Fig. 6. Following the initial penetration-extraction cycle, the soil was remoulded for 15 cycles at a rate of $3 \mathrm{~mm} / \mathrm{s}$, and then cycles at decreasing rates were applied down to $0.03125 \mathrm{~mm} / \mathrm{s}$. For the lowest rates (below $0.5 \mathrm{~mm} / \mathrm{s}$ ), the extraction was carried out at $1 \mathrm{~mm} / \mathrm{s}$ to limit the test duration to a practical time.

The material undrained shear strength was determined by

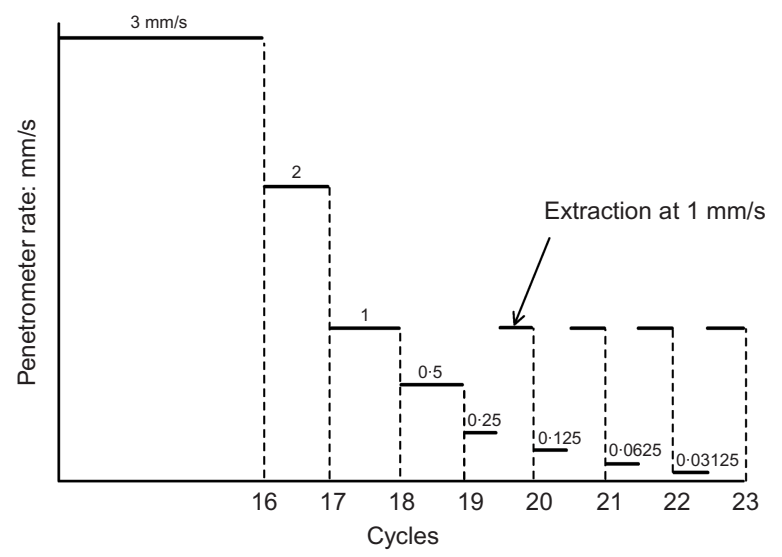

Fig. 6. Sequence of penetration rates applied with the T-bar and ball penetrometers 
averaging the penetration resistance over $\sim 20 \mathrm{~mm}$ displacement, using the resistance factor $N_{\mathrm{p}}=10 \cdot 5$. The shear strain rates were calculated using equation (10).

\section{RESULTS AND DISCUSSION}

Shear strength variation with water content

The vane shear measurements and viscometer data are combined in Fig. 7 for kaolin and Burswood clay. The data extend over a range of water content between 51\% and $206 \%$ for kaolin (i.e. liquidity index, LI, between 0.77 and $5 \cdot 86$ ), and between $66 \%$ and $230 \%$ for Burswood clay (i.e. LI between 0.65 and 3.54). The strength plotted in Fig. 7 is the peak value measured during the first rotation phase at $1 \%$, corresponding to a shear strain rate of $0.5 \mathrm{~s}^{-1}$.

Figure 7(a) shows a continuous decrease in undrained shear strength with water content increase for each soil. The effect of water content increase is dramatic, and eclipses the influences of strain rate and remoulding, which are discussed later. The strength is reduced by over three orders of magnitude as the water content is multiplied by a factor of about 4. This evolution can be represented by a power function of the form

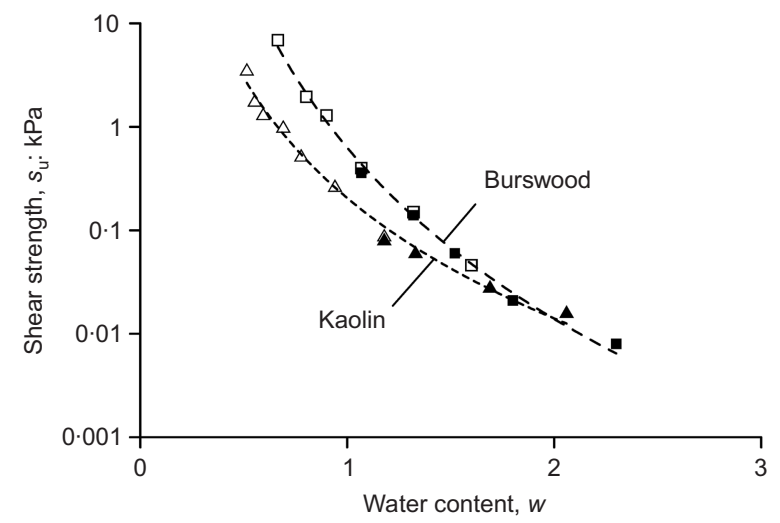

(a)

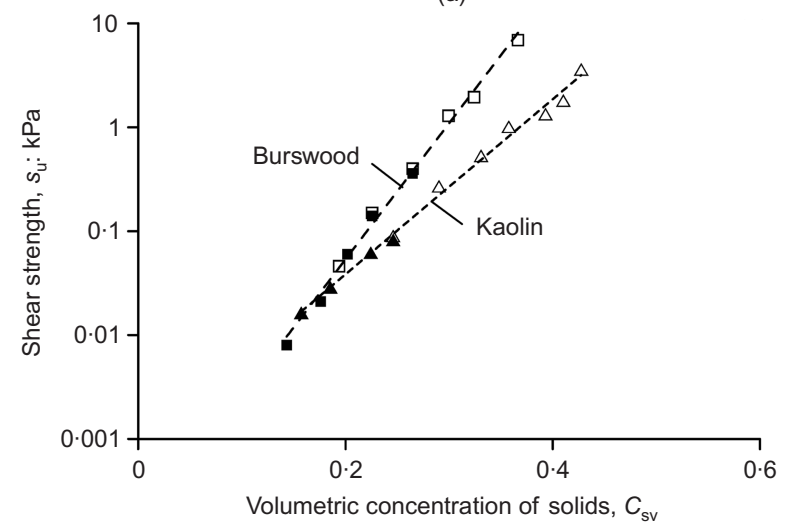

(b)

Fig. 7. Variation of shear strength: (a) with water content; (b) with volumetric sediment concentration. Data are initial peak values at $1 \% \mathrm{~s}$ measured with vane (empty symbols) and viscometer (full symbols)

$$
s_{\mathrm{u}}=a_{1} w^{-b_{1}}
$$

where the parameters $a_{1}$ and $b_{1}$ for each soil are given in Table 2 .

By applying the classical normalisation of the water content in terms of the liquidity index, LI, both curves representing the shear strength of the two soils converge towards the CSL defined in equation (2) in the lower range of LI (in Fig. 8 the CSL is plotted for $L I \leqslant 1$ ). The data can now be fitted by a power function of the form

$$
s_{\mathrm{u}}=a_{2}(\mathrm{LI})^{-b_{2}}
$$

with the parameters $a_{2}$ and $b_{2}$ listed in Table 2 for the two soils. A similar power function was proposed by Locat \& Demers (1988) to represent the remoulded undrained shear strength of sensitive clay soils for LI in the range 1.5-6, with parameters $a_{2}=1.46 \mathrm{kPa}$ and $b_{2}=2.44$. Jeong et al. (2009) reported values of $a_{2}=0.90 \mathrm{kPa}$ and $b_{2}=3 \cdot 4$, deduced from tests on a clay from eastern Canada. Another relationship was derived by Leroueil et al. (1983), from fall cone measurements on a variety of clays from Canada and elsewhere, in the form $s_{\mathrm{u}}=1 /(\mathrm{LI}-0 \cdot 21)^{2}$, for values of LI between 0.4 and 3. This relationship is plotted in Fig. 8, and agrees well with the kaolin data.

In order to compare this set of data with other published data presented according to the fluid mechanics framework, it is of interest to plot the undrained shear strength as a function of the volumetric concentration of solids, $C_{\mathrm{sv}}$. Fig. 7(b) shows that the behaviour of kaolin and Burswood clay can be represented well by the exponential function

$$
s_{\mathrm{u}}=a_{3} \mathrm{e}^{b_{3} C_{\mathrm{sv}}}
$$

with the values of $a_{3}$ and $b_{3}$ given in Table 2 for the two soils. Equation (13) is similar to the empirical relationship generally used to relate the yield stress of fluids to $C_{\mathrm{sv}}$, and the values of $a_{3}$ and $b_{3}$ are within the ranges reported in the literature (O’Brien \& Julien, 1988; Major \& Pierson, 1992).

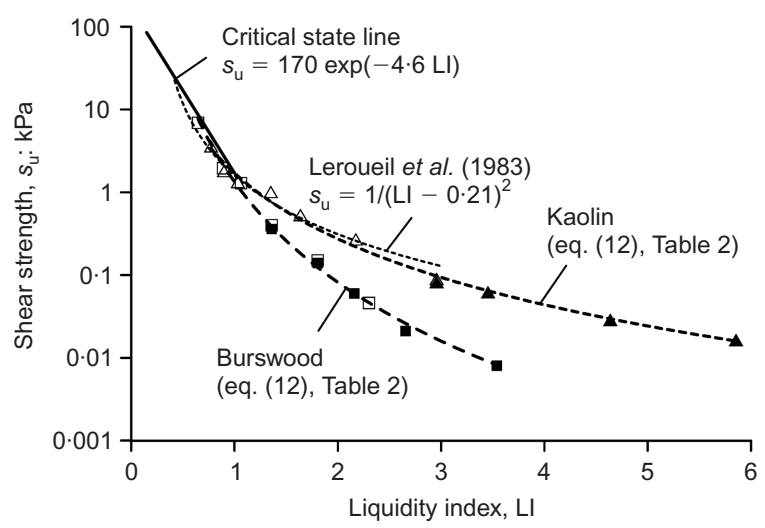

Fig. 8. Variation of shear strength with liquidity index (same data as Fig. 7), critical state line (for $L I \leqslant 1$ ) and relationship derived by Leroueil et al. (1983)

Table 2. Parameters describing $s_{\mathrm{u}}$ as a function of $w, \mathrm{LI}, C_{\mathrm{sv}}$, best-fitted to the vane and viscometer data

\begin{tabular}{l|c|c|c|c|c|c}
\hline \multirow{2}{*}{ Soil } & \multicolumn{2}{|c|}{ Equation (11) } & \multicolumn{2}{c|}{ Equation (12) } & \multicolumn{2}{c}{ Equation (13) } \\
\cline { 2 - 7 } & $a_{1}: \mathrm{kPa}$ & $b_{1}$ & $a_{2}: \mathrm{kPa}$ & $b_{2}$ & $a_{3}: \mathrm{kPa}$ & $b_{3}$ \\
\hline Kaolin & 0.205 & 3.86 & 1.71 & 2.64 & $7.96 \times 10^{-4}$ & 19.4 \\
Burswood & 0.629 & 5.50 & 1.34 & 4.03 & $1.29 \times 10^{-4}$ & $30 \cdot 2$ \\
\hline
\end{tabular}


The data are equally well correlated with each of the three equations $\left(R^{2}=0.99\right)$. When using non-normalised parameters (Fig. 7), the strength measurements for the two soils appear to converge in the low-strength range (liquid range). In this range the contact between the particles may have less effect on the strength, and instead the flow of water between the particles as they rearrange - which is related to the available pore space - may have a stronger influence on the resistance, and hence better agreement between the two soils when compared with $C_{\mathrm{sv}}$ or $w$. In the range of $\mathrm{LI}<1$, the normalisation through the liquidity index seems to capture the effects related to soil type, as is conventionally found in geotechnical engineering. However, any transition in the governing behaviour is gradual and continuous, and there is no evidence of a distinct phase transformation at a boundary between regions of solid and fluid behaviour. Instead, equations (11)-(13) capture accurately the strength behaviour across the range $0 \cdot 01-10 \mathrm{kPa}$.

\section{Comparison of the different tests}

The vane shear undrained shear strength at various water contents is compared with the fall cone, T-bar and ball strengths in Figs 9 and 10 for kaolin and Burswood clay respectively. Note that the T-bar and ball strengths plotted in these figures correspond to the initial penetration at $3 \mathrm{~mm} / \mathrm{s}$. These figures also show the line fitted through the vane and viscometer data and represented by equation (11). From these figures, it appears that the various measurements compare reasonably well. To quantify the scatter in the data obtained with each method, the measured strength as a function of water content can be approximated by a power

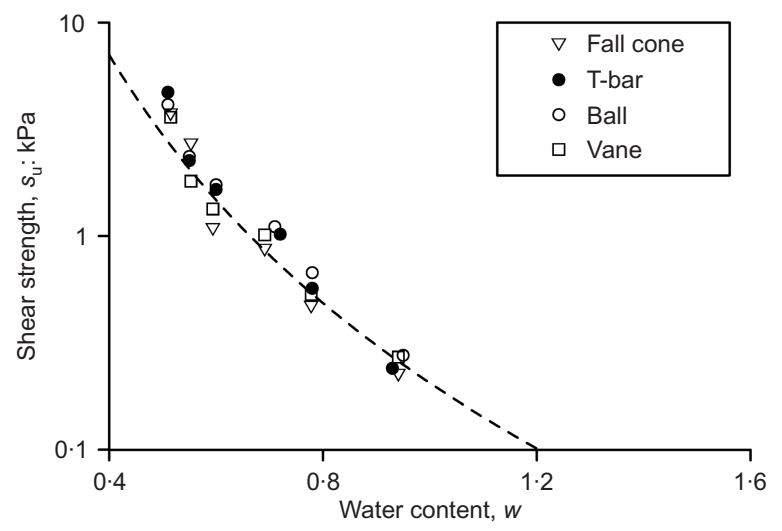

Fig. 9. Comparison of different measurements of kaolin initial undrained shear strength

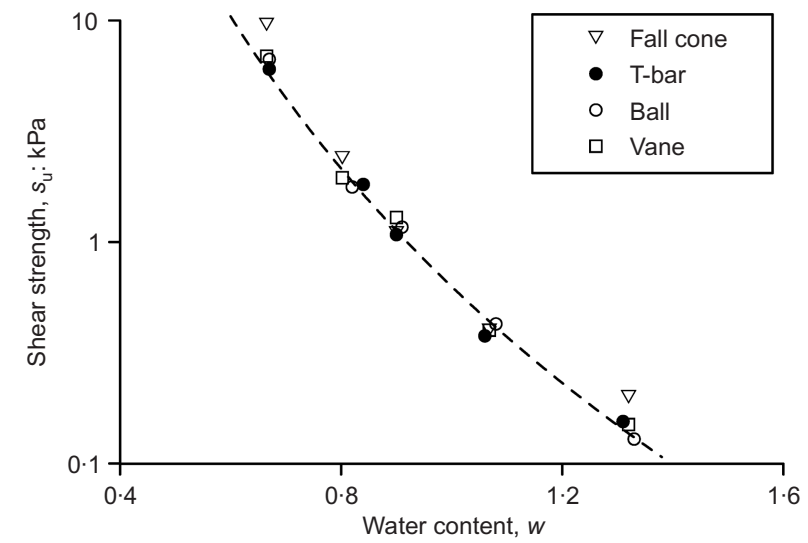

Fig. 10. Comparison of different measurements of Burswood clay initial undrained shear strength function of the form given in equation (11). The best fit of this form of equation has been determined for the set of data from each type of test. The resulting coefficient of determination, $R^{2}$, provides an indication of the scatter obtained through each type of test. These values are given in Table 3, and indicate that the data obtained with the fall cone test are more scattered compared with the other measurements methods.

\section{Effect of strain rate}

The various strength measurement methods operate at different strain rates. Fig. 11 represents the various strength measurements relative to their operative strain rate (based on Figs 9 and 10). The strength measured with each test is compared with the vane shear strength, and this strength ratio is averaged over all water contents. The operative strain rates are $\sim 3 \mathrm{~s}^{-1}$ for the fall cone (typical value; Koumoto \& Houlsby, 2001), $\sim 0.5 \mathrm{~s}^{-1}$ for the vane shear $(1 \% \mathrm{~s})$, and $\sim 0.09 \mathrm{~s}^{-1}$ for the T-bar and ball (a $10 \mathrm{~mm}$ T-bar penetrating at $3 \mathrm{~mm} / \mathrm{s}$ ). As can be seen in Fig. 11, the data for Burswood clay follow the trend of the logarithmic model with the typical value of $\mu=0 \cdot 15$. However, the data for kaolin show a reverse trend. The higher strength obtained with the penetrometer for kaolin may be attributed to the fact that less strain is induced in the soil during the initial penetration of the T-bar or ball, compared with the insertion and initial shearing of the vane. It is therefore unclear whether the difference in strength measurement obtained with the different devices is due to a strain rate effect or a strain accumulation effect (i.e. remoulding), or an inaccuracy in the interpretation method. The discussion that follows focuses on strain rate effect solely, analysing data obtained within one measurement method, after sufficient remoulding of the soil to eliminate effects of strain accumulation (i.e. the level of remoulding).

Measurements of the undrained shear strength of kaolin with the T-bar at various penetration rates show an increase in strength as the rate increases. This is depicted in Fig. 12,

Table 3. Coefficient of determination, $R^{2}$, for best-fitted power function approximation of strength as a function of water content (equation (11)) for each test type

\begin{tabular}{l|c|c|c|c}
\hline & Fall cone & Vane & T-bar & Ball \\
\hline Kaolin & 0.96 & 0.97 & 0.97 & 0.99 \\
Burswood & 0.97 & 0.99 & 0.99 & 1.00 \\
\hline
\end{tabular}

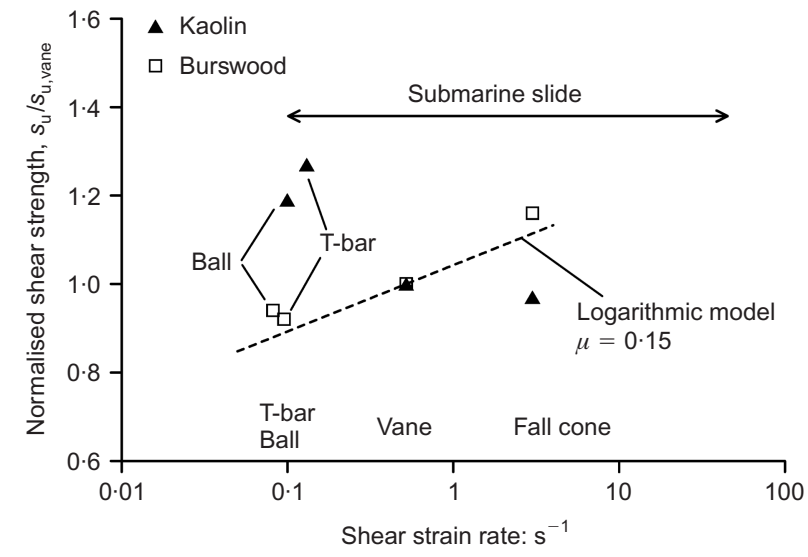

Fig. 11. Initial undrained shear strength normalised by vane shear strength (averaged over all water contents) as a function of strain rate 


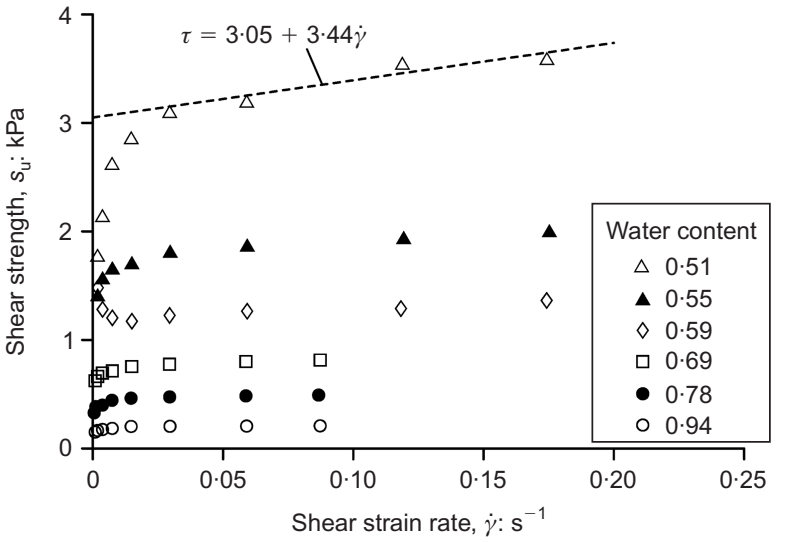

Fig. 12. Shear strength against shear strain rate for T-bar tests in kaolin at various water contents; Bingham fit shown for $w=0.51$

where the shear strain rate is computed from the T-bar penetration rate using equation (10). Except for the specimen at $59 \%$ water content, the data show a continuous nonlinear increase in shear stress with shear strain rate. The curves in Fig. 12 clearly demonstrate the limitation of the Bingham model for representing the material behaviour. This model overestimates the actual yield stress, regardless of the region of data to which it is fitted, as illustrated by the dashed line approximating the data for the sample at $51 \%$ water content. The model requires some refinements to be able to predict the yield stress adequately, as well as the non-linear strength increase at low shear strain rate.

For comparison with previously published data, it is of interest to estimate the Bingham parameters, namely the yield stress $\tau_{\mathrm{y}}$ and the viscosity $\eta$. This is achieved through linear interpolation of the data corresponding to the three higher strain rates. The Bingham parameters as a function of water content are reported in Table 4 for kaolin samples tested with the T-bar and ball penetrometers, and in Table 5 for Burswood clay samples. Similarly, Bingham parameters inferred from vane shear test measurements on kaolin are listed in Table 6. As depicted in Fig. 13 for kaolin, the viscosity parameter $\eta$ decreases over three orders of magnitude as the water content increases, following a similar trend to that of the yield stress $\tau_{\mathrm{y}}$. However, the ratio $\eta / \tau_{\mathrm{y}}$ does not show a systematic change with water content, and may be approximated as constant. Note also that the values obtained for the viscosity parameter from the penetrometer measurements are 1000 times larger than those obtained from the vane shear measurements. This can be explained by the fact that the vane operates at much higher strain rates than the penetrometers (by a factor of approximately 1000), and therefore the data points obtained with the vane lie on the flattening portion of the non-linear strength-strain-rate relationship. This is a weakness of the Bingham model, that

Table 4. Rheological parameters for kaolin inferred from penetrometer tests

\begin{tabular}{|c|c|c|c|c|c|c|c|c|}
\hline$w$ & $s_{\mathrm{u}, \mathrm{ref}}: \mathrm{kPa}$ & $\mu$ & $R^{2}$ & $\beta$ & $R^{2}$ & $\tau_{\mathrm{y}}: \mathrm{kPa}$ & $\eta: \mathrm{Pa} \cdot \mathrm{s}$ & $\eta / \tau_{\mathrm{y}}: \mathrm{s}$ \\
\hline $\begin{array}{l}\text { T-bar } \\
0 \cdot 51 \\
0 \cdot 55 \\
0 \cdot 59 \\
0 \cdot 69 \\
0 \cdot 78 \\
0 \cdot 94\end{array}$ & $\begin{array}{l}3 \cdot 36 \\
1.97 \\
1.33 \\
0 \cdot 84 \\
0.51 \\
0.22\end{array}$ & $\begin{array}{l}0 \cdot 26 \\
0 \cdot 15 \\
0 \cdot 13 \\
0 \cdot 12 \\
0 \cdot 14 \\
0 \cdot 13\end{array}$ & $\begin{array}{l}0.96 \\
0.98 \\
0.94 \\
0.99 \\
0.94 \\
0.92\end{array}$ & $\begin{array}{l}0 \cdot 140 \\
0 \cdot 070 \\
0 \cdot 055 \\
0 \cdot 056 \\
0 \cdot 068 \\
0 \cdot 063\end{array}$ & $\begin{array}{l}0 \cdot 92 \\
0 \cdot 96 \\
0 \cdot 95 \\
0 \cdot 99 \\
0 \cdot 91 \\
0 \cdot 91\end{array}$ & $\begin{array}{l}3 \cdot 05 \\
1 \cdot 81 \\
1 \cdot 20 \\
0 \cdot 76 \\
0 \cdot 47 \\
0 \cdot 20\end{array}$ & $\begin{array}{r}3440 \\
1133 \\
859 \\
672 \\
302 \\
73\end{array}$ & $\begin{array}{l}1 \cdot 13 \\
0 \cdot 63 \\
0 \cdot 72 \\
0 \cdot 88 \\
0 \cdot 64 \\
0 \cdot 37\end{array}$ \\
\hline $\begin{array}{l}\text { Ball } \\
0 \cdot 51 \\
0 \cdot 55 \\
0 \cdot 59 \\
0 \cdot 69 \\
0 \cdot 78 \\
0.94\end{array}$ & $\begin{array}{l}2 \cdot 84 \\
2 \cdot 11 \\
1 \cdot 39 \\
0 \cdot 95 \\
0 \cdot 58 \\
0 \cdot 23\end{array}$ & $\begin{array}{l}0 \cdot 16 \\
0 \cdot 18 \\
0 \cdot 08 \\
0 \cdot 04 \\
0 \cdot 04 \\
0 \cdot 03\end{array}$ & $\begin{array}{l}0.92 \\
0.98 \\
0.99 \\
0.95 \\
0.97 \\
0.92\end{array}$ & $\begin{array}{l}0.076 \\
0.087 \\
0.037 \\
0.020 \\
0.020 \\
0.015\end{array}$ & $\begin{array}{l}0.91 \\
0.97 \\
0.99 \\
0.95 \\
0.97 \\
0.92\end{array}$ & $\begin{array}{l}2 \cdot 75 \\
2 \cdot 04 \\
1 \cdot 34 \\
0 \cdot 94 \\
0 \cdot 56 \\
0 \cdot 22\end{array}$ & $\begin{array}{r}1466 \\
1313 \\
667 \\
81 \\
316 \\
116\end{array}$ & $\begin{array}{l}0 \cdot 53 \\
0 \cdot 64 \\
0 \cdot 50 \\
0.09 \\
0.56 \\
0.53\end{array}$ \\
\hline
\end{tabular}

Note: $\dot{\gamma}_{\text {ref }}=0.06 \mathrm{~s}^{-1}$; strain rate range $0.001 \leqslant \dot{\gamma} \leqslant 0.175 \mathrm{~s}^{-1}$.

Table 5. Rheological parameters for Burswood clay inferred from penetrometer tests

\begin{tabular}{|c|c|c|c|c|c|c|c|c|}
\hline$w$ & $s_{\mathrm{u}, \mathrm{ref}}: \mathrm{kPa}$ & $\mu$ & $R^{2}$ & $\beta$ & $R^{2}$ & $\tau_{\mathrm{y}}: \mathrm{kPa}$ & $\eta: \mathrm{Pa} \cdot \mathrm{s}$ & $\eta / \tau_{\mathrm{y}}: \mathrm{s}$ \\
\hline $\begin{array}{l}\text { T-bar } \\
0 \cdot 67 \\
0 \cdot 84 \\
0.90 \\
1.06 \\
1.31\end{array}$ & $\begin{array}{l}5 \cdot 34 \\
1.52 \\
0 \cdot 98 \\
0 \cdot 34 \\
0 \cdot 13\end{array}$ & $\begin{array}{l}0 \cdot 06 \\
0 \cdot 06 \\
0 \cdot 12 \\
0 \cdot 12 \\
0 \cdot 11\end{array}$ & $\begin{array}{l}0.95 \\
0.94 \\
0.97 \\
0.97 \\
0.90\end{array}$ & $\begin{array}{l}0 \cdot 026 \\
0 \cdot 029 \\
0 \cdot 054 \\
0 \cdot 057 \\
0 \cdot 050\end{array}$ & $\begin{array}{l}0.94 \\
0.95 \\
0 \cdot 97 \\
0.96 \\
0 \cdot 88\end{array}$ & $\begin{array}{l}5 \cdot 33 \\
1 \cdot 41 \\
0 \cdot 97 \\
0 \cdot 29 \\
0 \cdot 12\end{array}$ & $\begin{array}{r}399 \\
1753 \\
869 \\
383 \\
110\end{array}$ & $\begin{array}{l}0 \cdot 07 \\
1 \cdot 24 \\
0 \cdot 90 \\
1 \cdot 32 \\
0 \cdot 92\end{array}$ \\
\hline $\begin{array}{l}\text { Ball } \\
0 \cdot 67 \\
0 \cdot 82 \\
0 \cdot 91 \\
1 \cdot 08 \\
1 \cdot 33\end{array}$ & $\begin{array}{l}5 \cdot 13 \\
1.55 \\
0 \cdot 99 \\
0 \cdot 36 \\
0 \cdot 14\end{array}$ & $\begin{array}{l}0 \cdot 08 \\
0 \cdot 15 \\
0 \cdot 12 \\
0 \cdot 13 \\
0 \cdot 21\end{array}$ & $\begin{array}{l}0 \cdot 81 \\
0 \cdot 82 \\
0 \cdot 91 \\
1 \cdot 00 \\
0 \cdot 87\end{array}$ & $\begin{array}{l}0.034 \\
0.067 \\
0.053 \\
0.057 \\
0.107\end{array}$ & $\begin{array}{l}0.82 \\
0.83 \\
0.92 \\
1.00 \\
0.85\end{array}$ & $\begin{array}{l}4 \cdot 96 \\
1 \cdot 32 \\
0 \cdot 90 \\
0 \cdot 32 \\
0 \cdot 12\end{array}$ & $\begin{array}{r}2548 \\
3955 \\
1550 \\
409 \\
28\end{array}$ & $\begin{array}{l}0 \cdot 51 \\
3 \cdot 00 \\
1 \cdot 72 \\
1 \cdot 28 \\
0 \cdot 23\end{array}$ \\
\hline
\end{tabular}

Note: $\dot{\gamma}_{\text {ref }}=0.06 \mathrm{~s}^{-1} ;$ strain rate range $0.001 \leqslant \dot{\gamma} \leqslant 0.175 \mathrm{~s}^{-1}$. 
Table 6. Rheological parameters for kaolin inferred from vane shear and viscometer tests

\begin{tabular}{|c|c|c|c|c|c|c|c|c|}
\hline$w$ & $s_{\mathrm{u}, \mathrm{ref}}: \mathrm{kPa}$ & $\mu$ & $R^{2}$ & $\beta$ & $R^{2}$ & $\tau_{\mathrm{y}}: \mathrm{kPa}$ & $\eta: \mathrm{Pa} \cdot \mathrm{s}$ & $\eta / \tau_{\mathrm{y}}: \mathrm{s}$ \\
\hline $\begin{array}{l}\text { Vane } \\
0 \cdot 51 \\
0 \cdot 55 \\
0 \cdot 59 \\
0 \cdot 69 \\
0 \cdot 78 \\
0 \cdot 94 \\
1 \cdot 18\end{array}$ & $\begin{array}{l}1.51 \\
0.89 \\
0.57 \\
0.50 \\
0.26 \\
0.12 \\
0.07\end{array}$ & $\begin{array}{l}0 \cdot 13 \\
0 \cdot 20 \\
0 \cdot 23 \\
0 \cdot 17 \\
0 \cdot 16 \\
0 \cdot 19 \\
0 \cdot 12\end{array}$ & $\begin{array}{l}0.92 \\
0.98 \\
0.96 \\
0.97 \\
0.96 \\
0.99 \\
0.83\end{array}$ & $\begin{array}{l}0.050 \\
0.072 \\
0.079 \\
0.061 \\
0.060 \\
0.066 \\
0.046\end{array}$ & $\begin{array}{l}0.92 \\
0.95 \\
0.94 \\
0.96 \\
0.96 \\
0.97 \\
0.81\end{array}$ & $\begin{array}{l}1.66 \\
1.08 \\
0.69 \\
0.58 \\
0.30 \\
0.15 \\
0.08\end{array}$ & $\begin{array}{l}3 \cdot 760 \\
1 \cdot 816 \\
1 \cdot 032 \\
1.020 \\
0 \cdot 523 \\
0 \cdot 185 \\
0 \cdot 121\end{array}$ & $\begin{array}{l}2 \cdot 26 \\
1 \cdot 67 \\
1 \cdot 49 \\
1 \cdot 77 \\
1 \cdot 72 \\
1 \cdot 25 \\
1.47\end{array}$ \\
\hline $\begin{array}{l}\text { Viscometer } \\
1 \cdot 18 \\
1 \cdot 33 \\
1 \cdot 69 \\
2 \cdot 06\end{array}$ & $\begin{array}{l}0 \cdot 04 \\
0 \cdot 03 \\
0 \cdot 01 \\
0 \cdot 01\end{array}$ & $\begin{array}{l}0 \cdot 28 \\
0 \cdot 32 \\
0 \cdot 28 \\
0 \cdot 23\end{array}$ & $\begin{array}{l}0.95 \\
0.98 \\
0 \cdot 93 \\
0.99\end{array}$ & $\begin{array}{l}0.090 \\
0 \cdot 101 \\
0 \cdot 091 \\
0.078\end{array}$ & $\begin{array}{l}0.91 \\
0.93 \\
0.9 \\
0.96\end{array}$ & $\begin{array}{l}0 \cdot 05 \\
0 \cdot 04 \\
0 \cdot 02 \\
0 \cdot 01\end{array}$ & $\begin{array}{r}0.044 \\
0.032 \\
-0.001 \\
0.006\end{array}$ & $\begin{array}{r}0 \cdot 84 \\
0.87 \\
-0 \cdot 06 \\
0 \cdot 60\end{array}$ \\
\hline
\end{tabular}

Note: $\dot{\gamma}_{\text {ref }}=0.06 \mathrm{~s}^{-1}$; strain rate range $0.5 \leqslant \dot{\gamma} \leqslant 105 \mathrm{~s}^{-1}$.

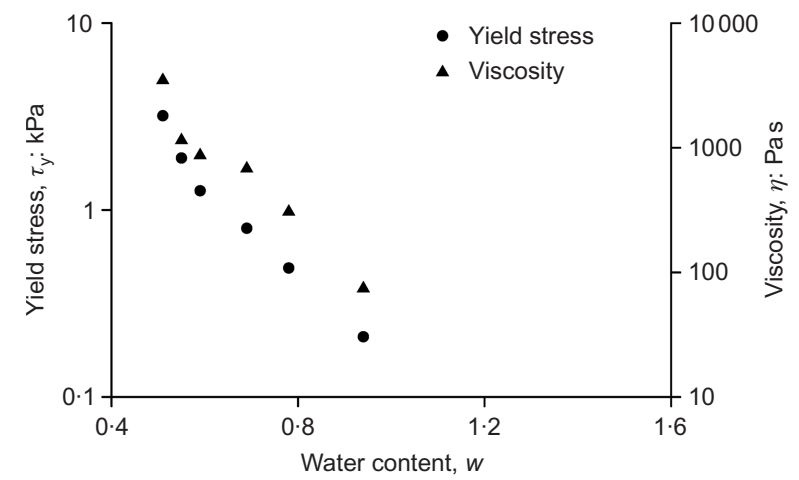

(a)

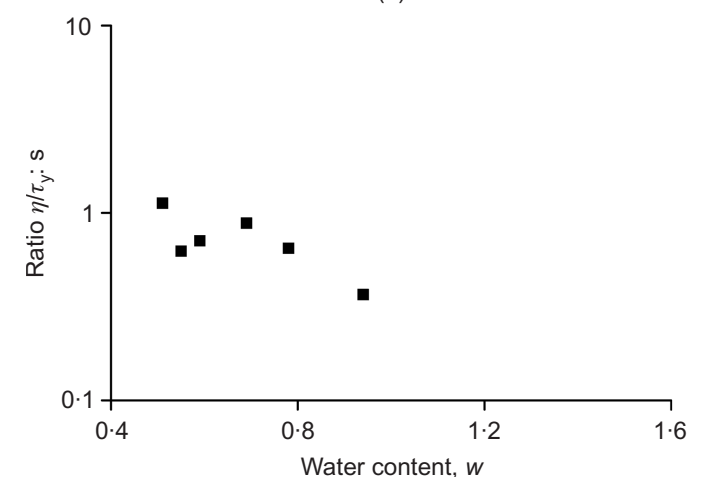

(b)

Fig. 13. Variation of Bingham parameters with water content from T-bar tests in kaolin: (a) yield stress $\tau_{\mathrm{y}}$ and viscosity $\eta$; (b) ratio $\eta / \tau_{\mathrm{y}}$

the model parameters vary according to the strain rate range under consideration.

The increase in undrained shear strength with shear strain rate can be better described using the logarithmic model (equation (3)) or the power law model (equation (4)). These two models assume that the shear strength can be estimated by multiplying a reference value of strength, $s_{\mathrm{u}, \mathrm{ref}}$, corresponding to a reference strain rate $\dot{\gamma}_{\text {ref }}$, by a logarithmic or power function of the normalised strain rate. In this work the reference strain rate is taken as $\sim 0.06 \mathrm{~s}^{-1}$, corresponding to a penetration rate of $1 \mathrm{~mm} / \mathrm{s}$ of the $5 \mathrm{~mm}$ diameter T-bar. The rheological parameters for the logarithmic and power law models as a function of the water content are reported in Tables 4 and 6 for kaolin, and in Table 5 for Burswood clay. The main observation is that the majority of the values obtained for the parameters $\mu$ and $\beta$ for both soils do not vary significantly with changes in water content, and are in the ranges $0 \cdot 1-0.2$ and $0.04-0.08$ respectively. The range of values obtained for the parameter $\beta$ compares well with the values estimated by Lehane et al. (2009) from penetrometer tests in kaolin. The data for some of the tests exhibit a lower strain-rate effect, in particular when testing kaolin with the ball (Table 4). In general, though, the rate parameters are not correlated with the water content. A similar finding was reported by Jeong et al. (2009), who observed that the power law parameter $\beta$ is independent of water content for low-activity clays tested with a viscometer. These authors reported an average value of $\beta$ around 0.12 for the six different soils tested.

The average and extreme curves representing the variation of normalised shear strength with normalised shear strain rates exhibited by the T-bar data for kaolin are shown in Fig. 14 for the logarithmic and power law models. The average logarithmic rate parameter for kaolin is $\mu=0 \cdot 15$, indicating a $15 \%$ increase in strength per order of magnitude increase in strain rate. Note that this effect is far less significant than the effect of water content on the strength (see above under 'Shear strength variation with water content'). Fig. 15 includes the vane shear measurements obtained at higher strain rates, together with the T-bar measurements. The corresponding average value for the parameter $\mu$ is $0 \cdot 18$ (the $R^{2}$ value for the regression is 0.94 , excluding the three anomalous data points for $w=0.59$, which are discussed below).

In Figs 14 and 15, the T-bar data corresponding to the kaolin sample at a water content of $59 \%(\mathrm{LI}=1.02)$ show an increase in shear strength with a decrease in shear strain rate below a strain rate of $0 \cdot 015 \mathrm{~s}^{-1}$. Similar effects are observed during ball penetration at slow rates in kaolin samples at water contents of $51 \%, 59 \%$ and $94 \%$ (Fig. 16). It is well recognised that at slow rates of penetration the resistance rises, owing to the onset of partial drainage (House et al., 2001; Chung et al., 2006). These results may be indicative of this effect. However, it is not clear why this effect is apparent only for some values of water content. For the estimation of the rate parameters $\mu$ and $\beta$, the anomalous low strain rate data are ignored.

Figure 17 depicts the average and extreme logarithmic curves representing the variation of normalised shear strength with normalised shear strain rates exhibited by the T-bar and ball measurements in Burswood clay samples at various water contents. Similarly as for kaolin, an increase in shear strength with a decrease in shear strain rate below a strain rate of $0.015 \mathrm{~s}^{-1}$ is observed during T-bar penetration for the sample at $90 \%$ water content $(\mathrm{LI}=1.06)$, and during 


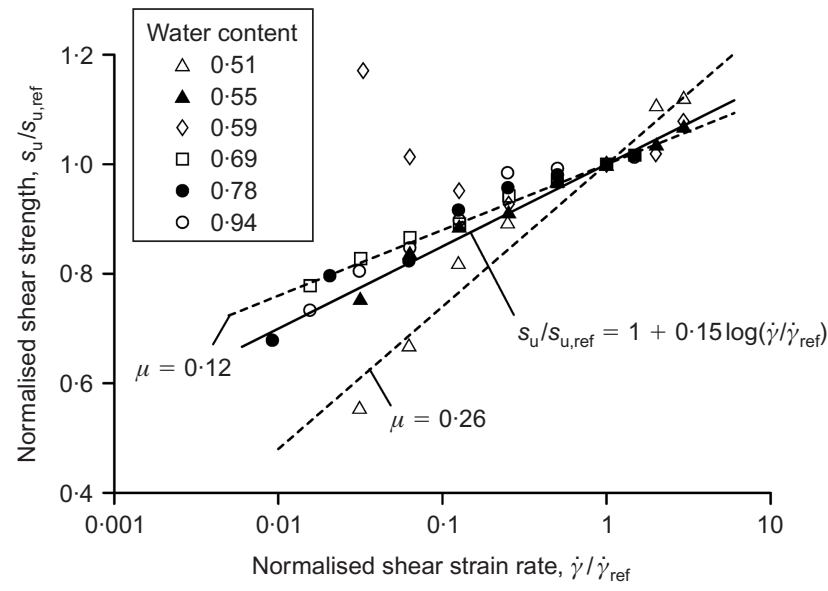

(a)

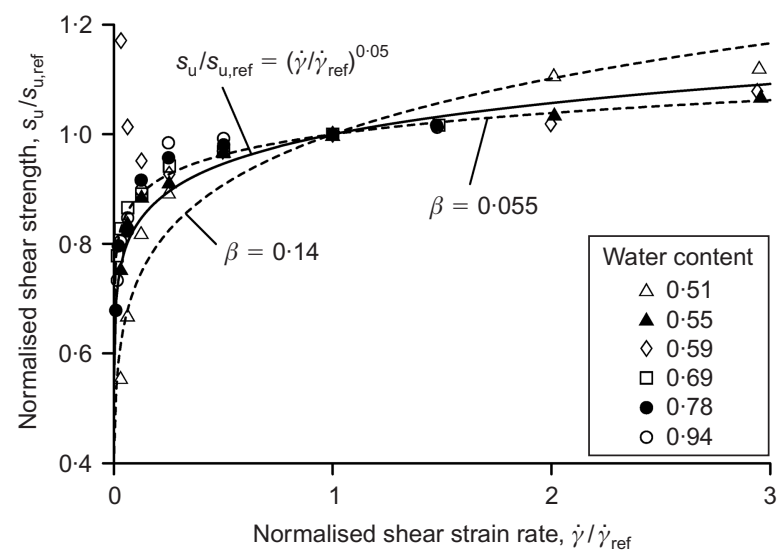

(b)

Fig. 14. Normalised shear strength against normalised shear strain rate for $T$-bar tests in kaolin at various water contents: (a) logarithmic interpolation; (b) power law interpolation

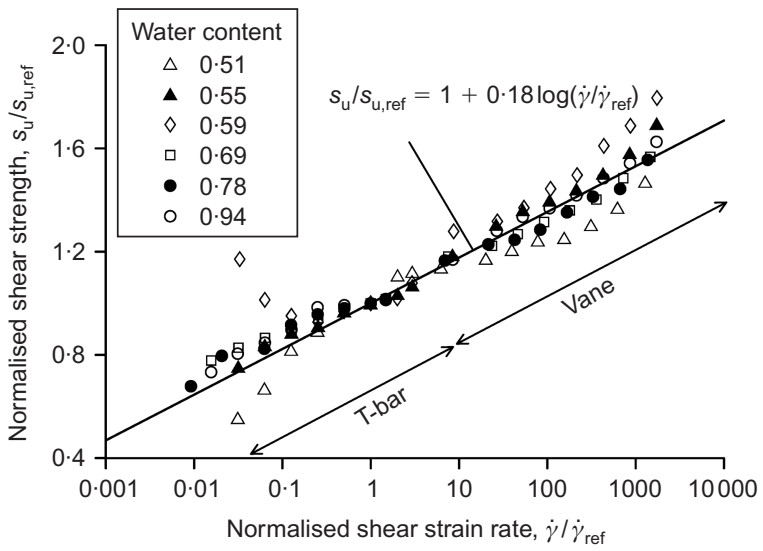

Fig. 15. Normalised shear strength against normalised shear strain rate (log scale) for $T$-bar and vane tests in kaolin at various water contents, and logarithmic interpolation

ball penetration for all the samples except the one with the largest water content, $w=133 \%$.

\section{Effect of strength degradation}

The strength degradation during prolonged shearing can be reflected by the sensitivity, defined as the ratio of the peak undrained shear strength and the residual undrained shear strength. In this study, for the vane shear test a peak strength is recorded during the initial rotation of the vane (or viscometer) at the reference rate of $1 \%$, whereas the

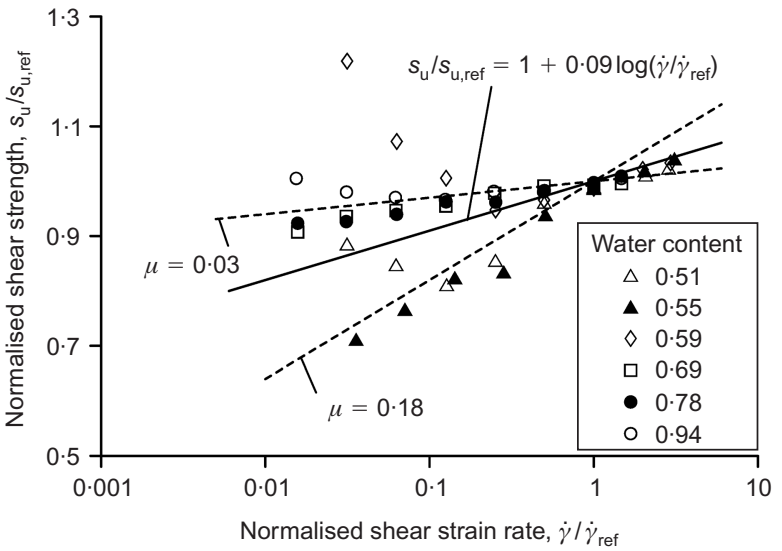

Fig. 16. Normalised shear strength against normalised shear strain rate (log scale) for ball tests in kaolin at various water contents, and logarithmic interpolation

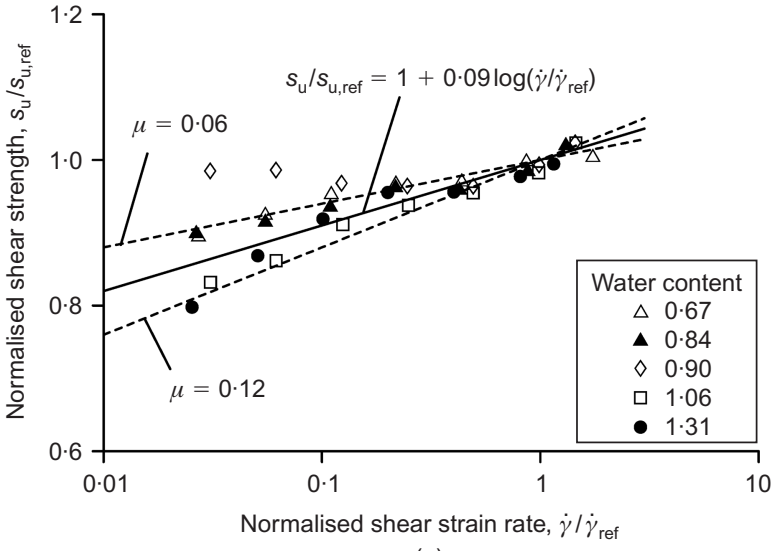

(a)

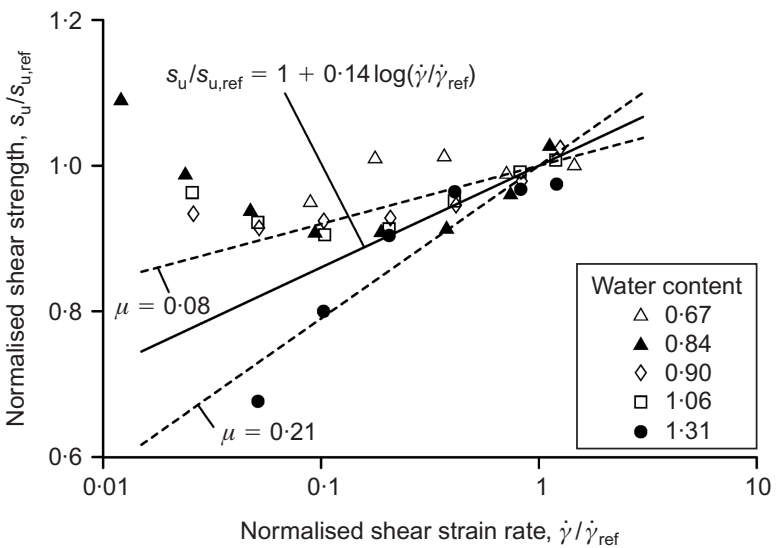

(b)

Fig. 17. Normalised shear strength against normalised shear strain rate in Burswood clay at various water contents, and logarithmic interpolation: (a) T-bar tests; (b) ball tests

residual strength is taken as the shear strength measured at the end of the vane shear test (or viscometer test), at the same reference rate of $1 \%$ s (see Fig. 5). For the T-bar and ball penetrometers, the sensitivity is determined as the ratio of the penetration resistance during the first penetration, and the resistance measured during the last remoulding cycle (cycle 16 in Fig. 6), both at $3 \mathrm{~mm} / \mathrm{s}$.

As plotted in Fig. 18, the sensitivities of kaolin and Burswood clay measured with the T-bar and ball range between 1 and 1.4 over the range of water contents considered. The data do not show any significant correlation between sensitivity and water content. The low values of 


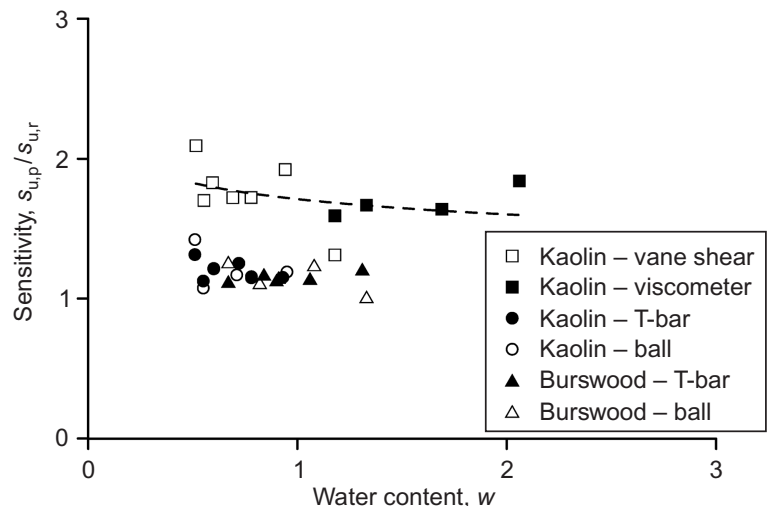

Fig. 18. Variation of sensitivity of kaolin and Burswood clay with water content

sensitivity are in accordance with the fact that the tests were carried out on soil that was remoulded during the specimen preparation. However, higher values of sensitivity were obtained from the vane shear (and viscometer) measurements, ranging between $1 \cdot 3$ and $2 \cdot 1$. It remains unclear why the resistance measured with the vane shear decreases significantly (compared with penetrometer measurements) as the soil is being remoulded. One possible explanation for this effect is contraction within the thin shear band created by the vane. In these soft soils there is a tendency for positive pore pressure to be generated on shearing, leading to contraction during pore pressure dissipation. The short drainage distance associated with the narrow shear band created by a vane means that the shear zone may be contracting within the duration of these long multi-stage tests, leading to low radial stresses and therefore low measured strength.

It should be noted that the degree of strength degradation evident in these tests was lower than would occur in intact samples of these soils, owing to the remoulding process involved in the sample preparation method.

\section{Combined model}

As a result of this study, a strength model has emerged that combines the influences of strain rate, remoulding and changes in moisture content across gross changes in the operative soil strength - spanning the solid-fluid boundary. By combining the previous equations, the model takes the form

$$
s_{\mathrm{u}}=a_{1} w^{-b_{1}}\left(\frac{\dot{\gamma}}{\dot{\gamma}_{\text {ref }}}\right)^{\beta}\left[\delta_{\text {rem }}+\left(1-\delta_{\text {rem }}\right) \mathrm{e}^{-3 \xi / \xi_{95}}\right]
$$

It has been shown that this model, with a single set of the material parameters, can characterise the response of a particular soil across three orders of magnitude in strength. Different parameters are required for different soils. Alternatively, equation (14) can be written using the logarithmic model (equation (3)) in place of the power law model. These relations are amenable to being incorporated in numerical modelling of large deformation processes. In these analyses, it is common to adopt a simple Tresca or von Mises failure criterion to describe the material strength, updating the strength at each material point according to the current strain rate or accumulated strain (e.g. Hu \& Randolph, 1998; Zhou \& Randolph, 2007). The results in this paper highlight how known changes in moisture content could also be incorporated in the same numerical modelling strategy, allowing the transition from solid to fluid to be captured without the need to consider multiple material phases.

\section{CONCLUDING REMARKS}

This paper has presented the results of a series of fall cone, vane shear and viscometer, T-bar and ball penetrometer tests on remoulded samples of kaolin and Burswood clay prepared at various water contents spanning the solidfluid boundary.

The motivation for this study is the requirement to characterise the strength of soils across the solid-fluid transition to aid the assessment of submarine slide hazards, and other geotechnical processes that involve heavy remoulding and water entrainment. The range of strength (or fluid shear stress) relevant to slide failure and run-out extends from the in situ geotechnical state through to values typically considered to be the domain of fluid mechanics models for material behaviour.

However, it has been shown that the material strength over a wide range of water content, extending to the fluid region, can be described within a soil mechanics strength modelling framework. This includes the effects on the material strength of water content, strain rate, and degree of remoulding.

A relation between undrained shear strength and water content is set out in the form of a power function involving two constants, which are found to be material dependent. The liquidity index is used as a normalised water content parameter to capture the strength variations of all soils through a unique critical state line between the Atterberg limits. However, it is shown that this normalisation cannot capture the same effect over the wider range of water content considered in this study. The analysis also demonstrated that the strength variations can be equivalently described by an exponential function of the volumetric concentration of solids $C_{\mathrm{sv}}$, following the classical fluid mechanics formulation where the yield stress is related to $C_{\text {sv }}$.

Careful attention has been given to the influence of strain rate in the interpretation of the different tests. It is important to recognise the different relative strain rates applied in conventional laboratory tests and in situ tests (both of which provide some freedom for rate effects to be investigated by changing the speed of the test). This study also highlights the wide range of strain rates involved in slide behaviour, and how they compare with the strain rates in the test methods, emphasising the importance of adopting a material model that captures rate dependence.

The effect of the strain rate on the mobilised shear strength is reasonably well captured by either a logarithmic model or a power law model over five orders of magnitude of strain rate, and over a wide range of water content. For both models the rate parameter is expressed in a dimensionless form, and this parameter shows no systematic variation with water content. The limitation of the Bingham fluid mechanics model, that it does not capture the non-linear strength variations at low strain rate, was demonstrated. The Herschel-Bulkley model allows this non-linearity to be captured (since it reduces to the same power law function as used in soil mechanics), but it retains the concept of additive (and therefore potentially independent) yield stress and ratedependent strength components. It is shown that an additive approach is unnecessary, since these two components vary in a similar manner as the water content is changed. Therefore a formulation in terms of a normalised stress and a normalised strain rate is preferable, as it leads to a unique nondimensional rate parameter.

The results show that the rate of strength degradation with the amount of shearing seems also not to be affected by the water content. This indicates that the strength degradation model can be applied with one set of material constants throughout the processes of remoulding and water entrainment that take place during a submarine slide or 
other event involving gross remoulding and changes in moisture content.

By collating all of these observations a combined strength model has been proposed, which can be implemented in large-deformation finite element programs. This provides an alternative to the classical fluid mechanics approaches of modelling submarine landslides, and avoids invoking a transition from the solid to the fluid phase. The proposed approach can also be used to assess the impact loading on pipelines or other infrastructure, via an appropriate resistance factor (in addition to any inertial component).

\section{ACKNOWLEDGEMENTS}

This work forms part of the activities of the Centre for Offshore Foundation System at UWA, which was established under the Australian Research Council's Special Research Centre scheme and is now supported by the State Government of Western Australia through the Centre of Excellence in Science and Innovation programme. The research presented in this paper is part of a Joint Industry Project administered and supported by the Minerals and Energy Research Institute of Western Australia, and by BP, BHP Billiton, Chevron, Petrobras, Shell and Woodside. The financial support of all the participants is gratefully acknowledged. This research is being undertaken within the CSIRO Wealth from Oceans Flagship Cluster on Subsea Pipelines. The fourth author acknowledges support from an International Postgraduate Research Scholarship, University Postgraduate Award from the University of Western Australia, and Benthic Geotech PhD Scholarship from Benthic Geotech Pty.

\section{NOTATION}

$a_{1}, b_{1}$ parameters describing the variation of $s_{4}$ as a function of $w$

$a_{2}, b_{2}$ parameters describing the variation of $s_{\mathrm{u}}$ as a function of LI

$a_{3}, b_{3}$ parameters describing the variation of $s_{\mathrm{u}}$ as a function of $\mathrm{C}_{\mathrm{sv}}$

$\mathrm{C}_{\mathrm{sv}}$ volumetric concentration of solids

$D$ diameter of vane, T-bar or ball

$e$ void ratio

$H$ height of vane

$h$ penetrated depth of fall cone

$p^{\prime}$ mean effective stress

$s_{\mathrm{u}} \quad$ undrained shear strength of clay

$s_{\text {u,ref }}$ shear strength at $\dot{\gamma}_{\text {ref }}$

$v$ specific volume $(=1+e)$

LI liquidity index

$K$ fall cone factor

$M$ critical stress ratio

$N$ specific volume at unit mean effective stress

$n$ rate parameter in the Herschel-Bulkley model

$N_{\mathrm{p}}$ resistance factor of penetrometer

$Q$ cone weight

$q$ penetration resistance of the T-bar or ball

$R$ average radius to centre of cylinders in viscometer

$T$ resisting torque measured with vane

$t$ gap between cylinders in viscometer

$w$ water content

$w_{\mathrm{PL}}, w_{\mathrm{LL}}$ water contents at plastic limit and liquid limit respectively

$\alpha_{1}, \alpha_{2}, \beta_{1}, \beta_{2}$ parameters describing the variation of yield stress and viscosity as a function of volumetric concentration of solids

$\beta$ rate parameter in the power law model

$\dot{\gamma}$ shear strain rate

$\dot{\gamma}_{\text {ref }}$ reference shear strain rate

$\delta_{\text {rem }}$ inverse of the sensitivity

$\eta$ viscosity of fluid

$\lambda$ one-dimensional compressibility

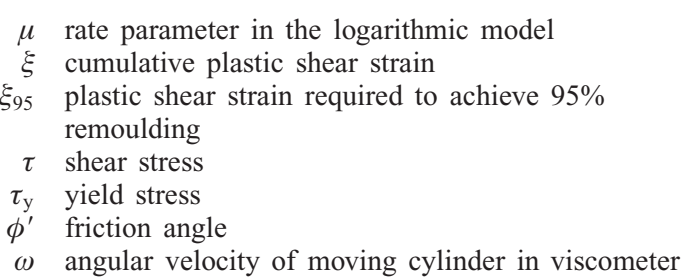

\section{REFERENCES}

Biscontin, G. \& Pestana, J. M. (2001). Influence of peripheral velocity on vane shear strength of an artificial clay. Geotech. Test. J. 24, No. 4, 423-429.

Bugge, T., Belderson, R. H. \& Kenyon, N. H. (1998). The Storrega slide. Phil. Trans. R. Soc. London 325, 357-388.

Chandler, R. J. (1988). The in-situ measurement of the undrained shear strength of clays using the field vane. In Vane shear strength testing of soils: Field and laboratory studies, ASTM Special Technical Publication 014, pp. 13-45. Philadelphia, PA: American Society for Testing and Materials.

Chung, S. F., Randolph, M. F. \& Schneider, J. A. (2006). Effect of penetration rate on penetrometer resistance in clay. ASCE J. Geotech. Geoenviron. Engng 132, No. 9, 1188-1196.

Coussot, F., Laigle, D. \& Arattano, M. (1998). Direct determination of rheological characteristics of debris flow. J. Hydraul. Engng 124, No. 8, 865-868.

Dayal, U. \& Allen, J. H. (1975). The effect of penetration rate on the strength of remolded clay and sand samples. Can. Geotech. J. 336, No. 3, 336-348.

De Blasio, F. V., Elverhoi, A., Issler, D., Harbitz, C. B., Bryn, P. \& Lien, R. (2004). Flow models of natural debris flows originating from overconsolidated clay materials. Marine Geol. 213, Nos 14, 439-455.

Einav, I. \& Randolph, M. (2005). Combining upper bound and strain path methods for evaluating penetration resistance. Int. J. Numer. Methods Engng 63, No. 4, 1991-2016.

Einav, I. \& Randolph, M. (2006). Effect of strain rate on mobilised strength and thickness of curved shear bands. Géotechnique 56, No. 7, 501-504, http://dx.doi.org/10.1680/geot.2006.56.7.501.

Gilbert, R. B., Nodine, M. C., Wright, S. G., Cheon, J. Y., Wrzyszczynski, M., Coyne, M. \& Ward, E. G. (2007). Impact of hurricane-induced mudslides on pipelines. Proc. Offshore Technology Conference, Houston, Paper OTC 18983.

Graham, J., Crooks, J. H. A. \& Bell, A. L. (1983). Time effects on the stress-strain behaviour of soft natural clays. Géotechnique 33, No. 3, 327-340, http://dx.doi.org/10.1680/geot.1983.33.3.327.

Hansbo, S. (1957). A new approach to the determination of the shear strength of clay by the fall cone test. Proc. R. Swedish Geotechnol. Inst. 14, 1-49.

House, A. R., Oliviera, J. R. M. S. \& Randolph, M. F. (2001). Evaluating the coefficient of consolidation using penetration tests, Int. J. Phys. Modelling Geotech. 1, No. 3, 17-25.

$\mathrm{Hu}$, Y. \& Randolph, M. F. (1998). A practical numerical approach for large deformation problems in soil. Int. J. Numer. Anal. Methods Geomech. 22, No. 5, 327-350.

Imran, J., Harff, P. \& Parker, G. (2001). A numerical model of submarine debris flow with graphical user interface. Comput. Geosci. 27, No. 6, 717-729.

Jeanjean, P., Liedtke, E., Clukey, E. C., Hampson, K. \& Evans, T. (2005). An operator perspective on offshore risk assessment and geotechnical design in geohazard-prone areas. Proc. Int. Symp. on Frontiers in Offshore Geotechnics (ISFOG 2005), Perth, 115143.

Jeong, S. W., Leroueil, S. \& Locat, J. (2009). Applicability of power law for describing the rheology of soils of different origins and characteristics. Can. Geotech. J. 46, No. 9, 1011-1023.

Koumoto, T. \& Houlsby, G. T. (2001). Theory and practice of the fall cone test. Géotechnique 51, No. 8, 701-712, http:// dx.doi.org/10.1680/geot.2001.51.8.701.

Lehane, B. M., O’Loughlin, C. D., Gaudin, C. \& Randolph, M. F. (2009). Rate effects on penetrometer resistance in kaolin. Géotechnique, 59, No. 1, 41-52, http://dx.doi.org/10.1680/ geot.2007.00072

Leroueil, S., Tavenas, F. \& Le Bihan, J.-P. (1983). Propriétés 
caractéristiques des argiles de l'est du Canada. Can. Geotech. J. 20, No. 4, 681-705

Locat, J. \& Demers, D. (1988). Viscosity, yield stress, remolded strength, and liquidity index relationships for sensitive clays. Can. Geotech. J. 25, No. 4, 799-806.

Locat, J. \& Lee, H. J. (2002). Submarine landslides: advances and challenges. Can. Geotech. J. 39, No. 1, 193-212.

Lunne, T. \& Andersen, K. H. (2007). Soft clay shear strength parameters for deepwater geotechnical design, Keynote Address. Proc. 6th Int. Offshore Site Investigation and Geotechnics Conf: Confronting New Challenges and Sharing Knowledge, London, $151-176$.

Major, J. J. \& Pierson, T. C. (1992). Debris flow rheology: experimental analysis of fine-grained slurries. Water Resour. Res. 28, No. 3, 841-857.

Marr, J. G., Elverhoi, A., Harbitz, C., Imran, J. \& Harr, P. (2002). Numerical simulation of mud-rich subaqueous debris flows on the glacially active margins of the Svalbard-Barents Sea. Marine Geol. 188, Nos 3-4, 351-364.

Masson, D. G., Harbitz, C. B., Wynn, R. B., Pedersen, G. \& Løvholt, F. (2006). Submarine landslides: processes, triggers and hazard prediction. Phil. Trans. R. Soc. A 364, No. 1845, 20092039.

McAdoo, B. G. \& Watts, P. (2004). Tsunami hazard from submarine landslides on the Oregon continental slope. Marine Geol. 203, Nos 3-4, 235-245.

Muir Wood, D. (1990). Soil behavior and critical state soil mechanics. Cambridge: Cambridge University Press.

Nguyen, Q. D. \& Boger, D. V. (1985). Direct yield stress measurement with the vane method. J. Rheol. 29, No. 3, 335-347.

O'Brien, J. S. \& Julien, P. Y. (1988). Laboratory analysis of mudflow properties. J. Hydraul. Engng 114, No. 8, 877-887.

Parker, E., Traverso, C. M., Giudice, T. D., Evans, T. \& Moore, R. (2009). Geohazard risk assessment-vulnerability of subsea structures to geohazards-some risk implications. Prof. Offshore Technology Conference, Houston, Paper OTC20090.

Randolph, M. F. (2004). Characterisation of soft sediments for offshore applications. Proc. 2nd Int. Conf. on Geotechnical and Geophysical Site Characterisation, Porto 1, 209-231.
Randolph, M. F. \& Houlsby, G. T. (1984). The limiting pressure on a circular pile loaded laterally in cohesive soil. Géotechnique 34, No. 4, 613-623, http://dx.doi.org/10.1680/geot.1984.34.4.613.

Roscoe, K. H., Schofield, A. N. \& Wroth, C. P. (1958). On the yielding of soils. Géotechnique 8, No. 1, 22-52, http:// dx.doi.org/10.1680/geot.1958.8.1.22.

Schofield, A. N. \& Wroth, C. P. (1968). Critical state soil mechanics. London: McGraw-Hill.

Schwab, W. C., Lee, H. J., Twichell, D. C., Locat, J., Nelson, H. C., McArthur, M. \& Kenyon, N. H. (1996). Sediment mass-flow processes on a depositional lobe, outer Mississippi Fan. J. Sediment. Res, 66, No. 5, 916-927.

Standards Australia (1991). Methods of testing soils for engineering purposes: Determination of the cone liquid limit of a soil, AS 1289.3.9. Perth: Standards Australia.

Standards Australia (1995). Methods of testing soils for engineering purposes: Determination of the plastic limit of a soil: Standard method, AS $1289 \cdot 3 \cdot 2 \cdot 1$. Perth: Standards Australia.

Stewart, D. P. \& Randolph, M. F. (1994). T-bar penetration testing in soft clay. J. Geotech. Engng, ASCE 120, No. 12, 2230-2235.

Wan, Z. (1982). Bed material movement in hyperconcentrated flow. J. Hydraul. Engng 111, No. 6, 987-1002.

Ward, S. N. (2001). Landslide tsunami. J. Geophys. Res. 106, No. 6, 11201-11215.

Wroth, C. P. \& Wood, D. M. (1978). The correlation of index properties with some basic engineering properties of soils. Can. Geotech. J. 15, No. 2, 137-145.

Zakeri, A. (2009). Review of state-of-the-art: Drag forces on submarine pipelines and piles caused by landslide or debris flow impact. J. Offshore Mech. Arctic Engng ASME 131, No. 1, Article no. 014001.

Zhou, H. \& Randolph, M. F. (2007). Computational techniques and shear band development for cylindrical and spherical penetrometers in strain-softening clay. ASCE Int. J. Geomech. 7, No. 4, $287-295$.

Zhou, H. \& Randolph, M. F. (2009). Resistance of full-flow penetrometers in rate-dependent and strain-softening clay. Géotechnique 59, No. 2, 79-86, http://dx.doi.org/10.1680/geot. 2007.00164 . 